\title{
マウス副腎皮質網狀層ノ組織的構造 站二其ノ機能二就テ
}

東京帝國大學傳染病研究所病理學部(主任長與敎授)

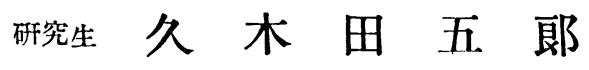

內容目次

緒 · 言

第一編 生後各時期二於ケル「マウス副腎殊 二皮質ノ發育狀態及ビ其ノ組織的構 造

第一章 動物ノ選定及ビ其他檢查二關スル 一般的注意

第二章 生後各發育時期ニ於ヶル副䇾殊二 皮質, 組織的所見

第三章 第一編事項二關スル文獻及ビ第二 章ノ總括的觀察

第二編 此倠. 雄マウス生殖腺ノ種マナル機能 狀態二因ル副腎殊二皮質, 變化

第一章 マウス」二於テ生殖腺除去 皮質二及ボス影響

第一項 文獻

第二項 試驗材料トシテ雄マウス選定及 ビ試驗二關スル一般的注意

第三項 雄マウス去勢後二於ヶル副腎殊 二皮質, 組織的所見

第四項 前項二關スル總括的觀察

第五項 檢查材料トシテノ雌マウス選定 二關スル注意

第六項 䧳マウス去勢後, 副腎皮質ノ組 織的所見二關スル總括的觀察

第二章 マウス」二於テ妊娠ノ副腎殊二皮 質二及ボス影響

第一項 文獻

第二項 檢査動物二關スル注意
第三項 妊娠時ニ於ケル「マウス副腎皮 質ノ組織的所見二關スル總括的 觀察

第三章 出座後二於ヶル「マウス副腎殊二 皮質, 變化

第一項 文獻

第二項 檢査材料動物選定二關スル注意

第三項 出產後ニ於ヶル「マウス副腎皮 質, 組織的所見

第四項 前項二關スル總括的觀察

第四章 生殖腺未熟マウス仔體內二腦下垂 體前葉成分輸入八副婜皮質二及ボ ス影響

第一項 文獻

第二項 檢査材料動物選乲二關スル注意

第三項 マゥフ仔體內二腦下垂體前葉成 分輸入後, 副腎皮質, 組織的所 見及ビ觀察

第四項 前項試驗後ニ於ヶル罳丸，所見 及ビ觀察

第五項 䧳マウス仔體內二腦下垂體前葉 成分輸入後, 副㹂皮質, 組織的 所見及ビ觀察

第三編 以上各章ニ於ヶル總括的觀察中，要 點

主要文虞 附圆說明 附圖 
副腎皮質實質細胞中特二網狀層二屬スル細胞八形態的性狀乃至生理的機能上二於テ最モ難解 且ツ興味アル題目卜シテ多ク著目サレ殊二生殖腺機能卜副腎皮質卜八相互的關係ニ於テモ該細 胞二特異ノ所見习認ムル點多キガ如ク從來或八剖檢材料ニョリ或八動物賽驗 究業績アリ (Methias. Schmidt. Bittorf. Schenk. Kolde. Wiesel. Altenburger. Stilling. Aichel. Gottschau. Guieysse. Novak. Leupold. Kolmer. Takechi. 增井. 田村. Tamura. Miller). 元來副 㱟皮質ヨ三層二分類セル八血管及ビ間質結締織, 走行及ビ各實質細胞，性狀及ビ配置ニョル極 メテ漠然タル區別ニシテ之レ等, 關係八各種哺乳動物ニ於テ著シキ相違ヨ示スト共=(Kolmer). 同種動物二於テモ各個體，性別年龄等二因ル一般生理的機能狀態. 特二生殖腺機能狀㦝 $/$ 相違二 因ル變化アリ。從テ從來各種實驗動物ニ於テ認メラレタル所見必ズシモ一致セズシテ諸家ノ觀察

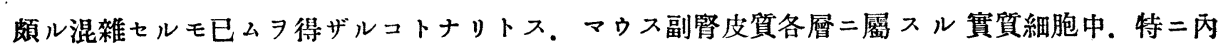
外/刺载二對シ反倠シ易ク不安定ナル存在 $コ$ 示ス八網狀層細胞ニシテ本細胞層卜索狀層間二形 成サル、境界及ビ兩層二蠋スル各細胞間二於ヶル相違等. 他種動物ノ夫レ等二比シ「マウス」ニ於

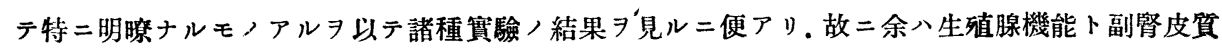
間二存スベキ關係ヨ觀察スル䨋二專ラ本動物ヨ使用セリ。

マウス副腎皮質ノ構造二關シテハ正常ノ場合. 雌雄性別ニョリ. 且ツ年齢ニョリ著シキ相違 示ス. 是レ等ニ關シテ二三詳細ナル觀察報告アリト雖(增井.田村. 別所. Miller)夫レ等 / 觀察所 見必ズシモ一致セザルヨ以テ余八先ッ゙正常動物ニ於ヶル生後ヨリ種々ノ時期二至ル發育ノ順序.

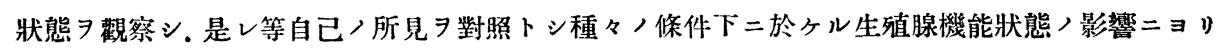

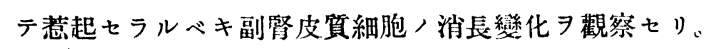

\section{第一編 生後各時期ニ於ヶル「マウス副觜特ニ皮質ノ發 育狀慰及ビ其ノ組織的構造 \\ 第一章 動物ノ選定及ビ其他檢查二關スルー般的注意}

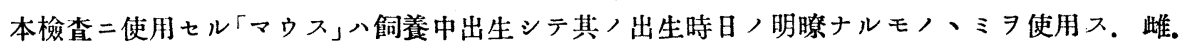
雄八生後 30 日ニシテ分離伺盖シ發有特二不艮ナルモノ八之レヨ除外ス. 生後副腎發育八狀態二 關シテハ同股動物ヨ種々, 時期二圪テ檢査シ.ソレ等所見, 異同习觀察セり。動物數八雄性二屬 スルモ, 60 匹二シテ出生當日ョリ生後 149 日二至り。雌性ニ於テハ 86 匹ニシテ同樣出生當日 リ生後 168 日二至ル種々ナル時期トス。生後 20 日一30日八大體二於テ雌雄間蓄シキ相違ナキ 以テ必ズシモ䧳雄各別ニ夫レ等ノ所見习訅述七ブ. 雨者間二漸次相違习認ムルニ至りテ初メテ各 別二記述スルモノトス. 本章二於テハ先ヅ生後各時期ニ於ヶル各個，所見习記載シ. 後チニ是レ 等所見习概括シテ觀察スルコト、シ。是レ等二關スル必要ナル文獻八各個，場合二於テ必要二應

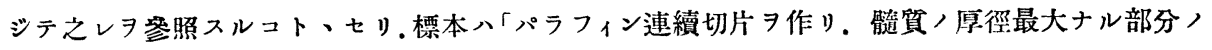
所見ヨ目標トシデレヨ觀察セリ。

\section{第二章 生後各發育時期ニ於ヶル副腎殊二皮侗ノ 組織的所見}

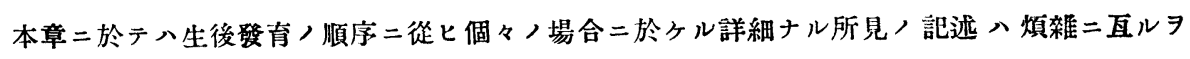


以テ立二生後發育中ノ或ル二, 三八時期ヨ選ビテ之レヨ記述シ。後子更二總括的ニ之レ等ヨ觀察 スルコト、スベシ。

\section{生後第 1 日 (第 265 號)}

副腎皮筫 被覆セル被膜八 2-3 列乃至 $5-6$ 列/紡錘形或八細長ナル核

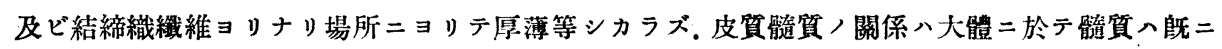

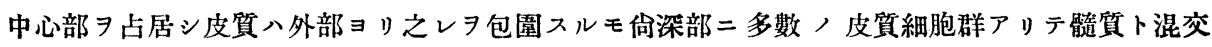

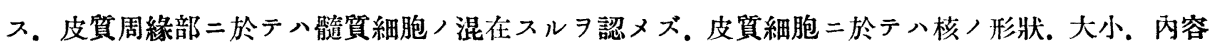
染色質, 多少. 配置, 狀態. 胞體內原形質, 多少. 染色程度. 細胞境界, 明否且ッ夫レ等，存在 スル位置的關係ニョリテ明暸二二形 $コ$ 分チ得ベシ。郎チ被膜直下二位置スル細胞ハ核小. 且ツ染 色質二富ミテ濃染シ。各胞體, 境界不明ニシテー栐ニ淡染セル胞體原形質内二核密接存在:シ以テ 一層ヨ形成ス. 之レ郎チ綵毢層ニシテ之ョリ內方二存スル細胞群卜八特別，境界ナクシテ漸次二 移行ス。此入內層細胞八核前者二比シテ直徑約二倍大多》、圆形胞狀ニシテ染色質ニ乏シク1一 2 個, 核小體 $\ni$ 含么。胞體冈原形質八前者二比シ幾分濃染シ。各個細胞，境界割合二明暸。各相 連ナリテ索狀ヨ形成シ. 各索八毛細血管及ビ僅少ノ結編織織維ニョリテ隔テラル. 細胞索ノ走行 八份不規則ニシテ成長セルモ,、索狀層二見ルが如キ正シキ配列 7 見ブ. 本層八幅員八絲毢層二 比スレバ 4-5 倍, 厚徑ヨ有ス。而シテ上訅兩層細胞間二八境界部二於テ明ラカニ移行型习認么 ルヨ得ベシ. 索狀層, 最內部艚質二接セル部分二八再ビ核小ニシテ幾分濃染シ. 胞體小ニシテ各

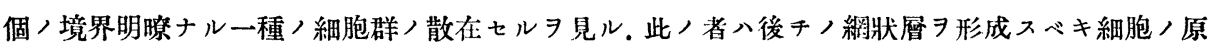

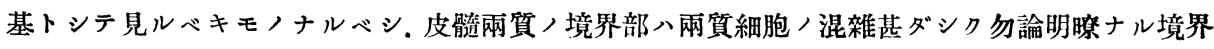

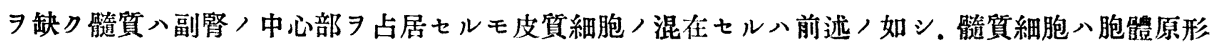
質エオシシン」難染ニシテルゴール氏液

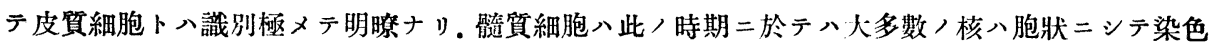
質ニ乏シク僅カ二核緣ヨ認ムルニ過ギザルモ,アリ。形狀多ク八圆形乃至整圆形。大小種々ア リ．細胞ノ配列雜然トシテ然カモ各個，境界明暸ナラズ．毛細血管，走行亦極メテ不規則ナリ。

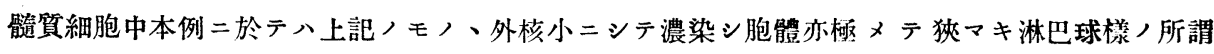
ジンパトゴニェン」㠈スルモノ八三三ヨ散見スルニ過ギズ。

\section{生後第 18 日 (第336 號) 雄}

‘前例二比シテ絲歯層索狀層二於テ八賽質細胞八間質結締織, 增殖スルニ從七各細胞群/境界

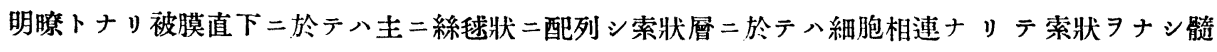

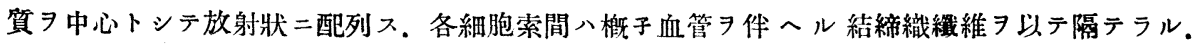
絲毢層細胞八其ノ核幾分小形ナルト配置二特異ノ點 認ムルノ外. 細胞體內溝狀ニ關シテハ索狀 層細胞ト大差ナシ. 索狀層細胞八各細胞境界割合二明暸ニシテ該層外牛部，細胞八胞體著シク蜂

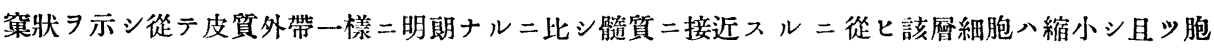

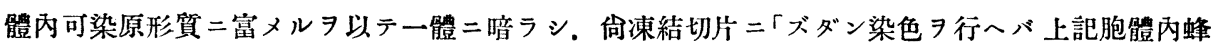

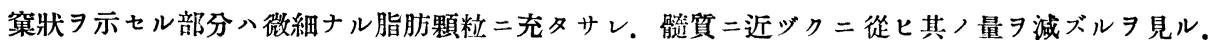
網狀層細胞群八生後 11 日頃二於テ既二其ノ數 $コ$ 增シ.漸ク網狀層, 構造認又得タルが.本例二於

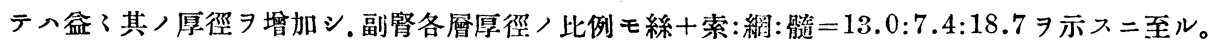
索狀層卜網狀層間八特別ノ境界 $コ$ 形成セブト踓。索狀層二於テハ核ノ配置疎ナルが故二層全骿卜 


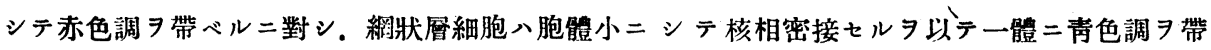
ブ故ニレヘマキシリン.エオシンン重染色標本二於テ明暸二兩層习區別スルコトヨ得ベシ。網狀 層細胞核八其,大小. 形狀. 核內容等索狀層細胞八夫レニ類似ス。然レドモ細胞體著シクホニシ テ索狀層細胞ニ於ヶルが如キ明暸ナル蜂窠狀構造 ヨ示サズシテ無構造ナルモ各個ノ境界八割合

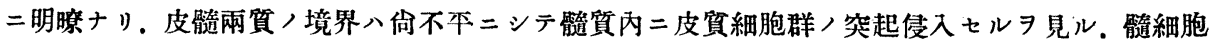
八生後 11 日ニシテ原形質二明カニ「クローム反憵ヨ現ハシ來ルガ本例ニ於テハ濃黄褐色. 淡黄色 等種々>程度二著色セル原形質ヨ有七ル細胞群互二混在シ。核へ大多數圆形ニシテ染色質二文 キモ。ソノ間多少小形且ツ染色筫二富メルモ, 及ビ少數, 萎縮セルモノ

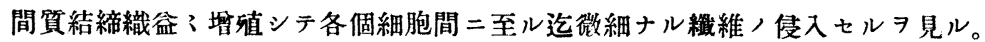

\section{生後第38 日 (第:341 號) 雄}

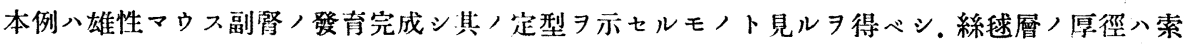

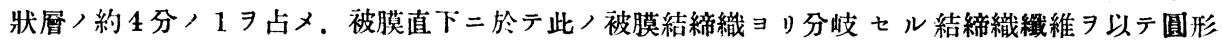
乃至檘圆形八 小分野 7 形成ス。其八内容細胞個々/境界八不明ニシテ核相密接ス。核八索狀層細

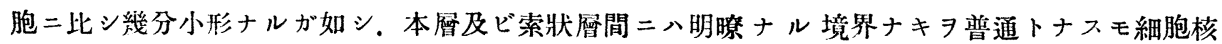

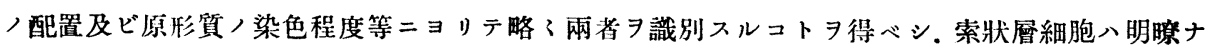

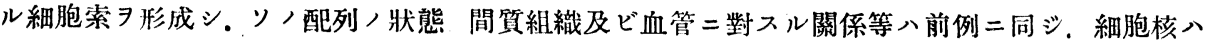

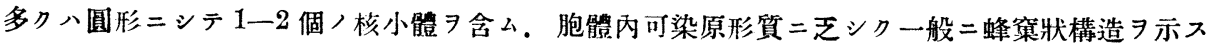

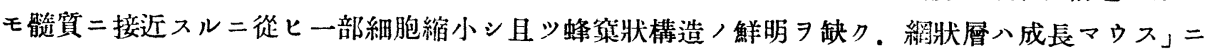
於テ從來特二注意サレシ事項ナルが本例二於テ繲狀層細胞トシテ見ルベキモ，八其，長軸习副

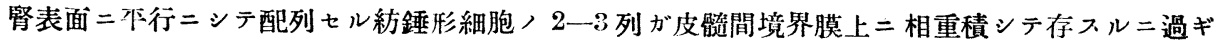

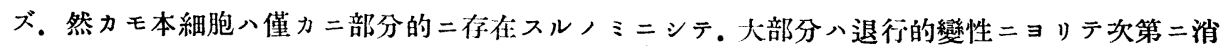
失シ去り僅カ二殘存セルモ,モ索狀層細胞二比シテ八核。胞體共二遥カ

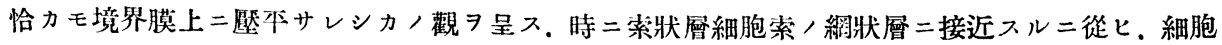
漸次其, 高サヨ減ジテ不平トナリ且ツ胞體內蜂策狀構造不明暸トナリテ上訅網狀層細胞卜，識 別困難ナルコトアリ．上彪セルが如キ網狀層細胞，退行的變性入䠶二生後 23 日(第 310 號)，モ ノ 二於テモ其ノ徵习認又得べキモ生後 30 日(第 608 號)二於テハ退化, 所見㙷著ニシテ各細胞,

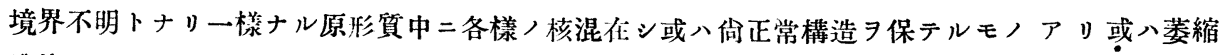
濃染七ルモノアリ。或八溶崩破碎セルモノアリ。然レドモ索狀曆細胞二八斯ル退行的傾向

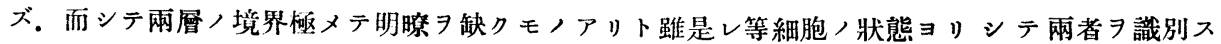
ルコトヨ得ベシ. 皮髓兩質境界八大體二於テ直線的二界サレ加之外表被膜二比シテ幾分菲薄ナ

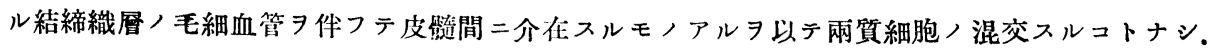

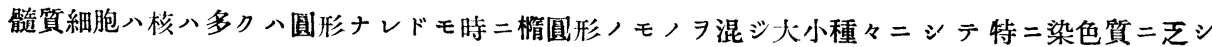
ク周圍原形質内二明輪 习劃ス。原形質, 色調八各細胞群ニョリテー楾ナラズ. 間質結締織ノ發有

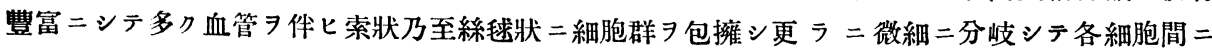
至ル。各細胞ノ境界割合二明暸ナリ。

生後 40 日. 雌 (268 號)

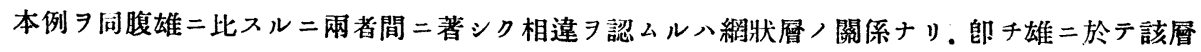
八此ノ時期ニ至レバ計測困難ナル程度二退化セルニ比シ本例ニ於テハ然ラズ. 絲毢層. 索狀層二 
就テン大體同腹雄性ト著シキ相違习認メブ. 索狀層細胞八胞體內原形質ニ乏シキト核ノ配置疎ナ ルヨ以テー樣ニ明帶ヨナセルニ對シ。網狀層細胞ハ「エオジン可染, 原形質二富ミ且ツ核比較的

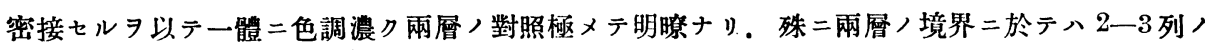
核密接セル細胞層アリテ岈廓大ヨ以テ之レヨ檢スレバ青色ノ一線トシテ認メラル。本境界層， 個々, 細胞八核ノ大小. 形狀. 核內容等索狀. 網狀兩層, 夫レ等卜大差ナキモ胞體極メテ小サ

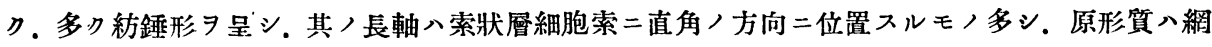
狀層細胞二比シ幾分エォジン」二濃染シ細胞境界割合二明暸ナリ．且ツ核ノ退化 兩層, 細胞二比シテ多キが如キモ侗同時二核, 間接分裂像 ヨ認ムルコトアリ。網狀層, 厚徑八

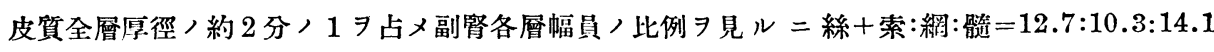

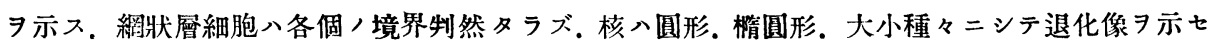
ルモ>混在シ配置疎密雜然タリ。細胞體內無構造ナル原形偭二富ミ䯣質二接近スルニ從七次第 二濃染スル傾向ヨ示ス. 此ノ外核二近ク一個ノ「ェオシン」二濃染スル顆粒习認ムルコトアリ。是 乙等, 細胞卜共二胞體內二空胞, 出現七ルモノアリ. 此ノ者八凍結切片二脂肪染色 脂肪顆䊉:因ルモノナルタ知ル，是レ等ノ空胞ノ大サハ種々ニシテ極メテ微細ナルモノョリ次第 三融合シテ大トナリ遂ニ八胞體內單一ナル空胞ニテ充タサル、モノアリ.而シテ通常索狀層細胞 體內二蜂窠狀構造 濃染シ或ハ溶崩破碎シ或ハ單二院影ヨ止ムルモノアリ。斯クシテ細胞八漸次二退化消失シ從テ網 牀層, 退縮习來スモノトス. 網狀層細胞二於ヶル斯ル退行的變化八一般成育雌性. 特二奸娠時二

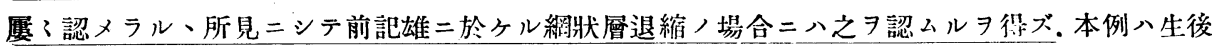

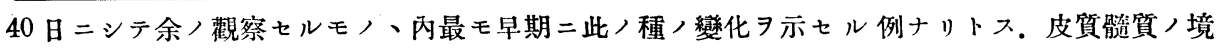
界極メテ不規則ニシテ皮質細胞ョリナル大小無數 $、$ 突起八䯇質內二侵入シ. 加之大小各種ノ皮

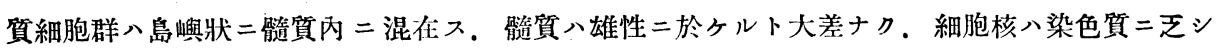
ク. 形狀多ク八圆形ニシテ大小種々ナり原形質八黄褐色乃至黄色二溚色セルモノ多ク細胞ハ絲 毢狀二群在七ルモノ多シ。

\section{生後 91 日. 雌 (第 530 號)}

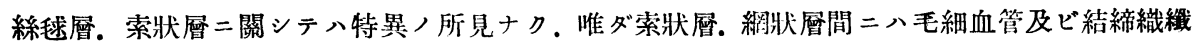

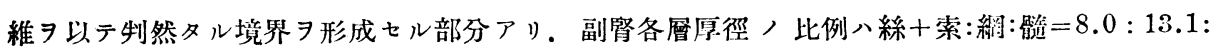

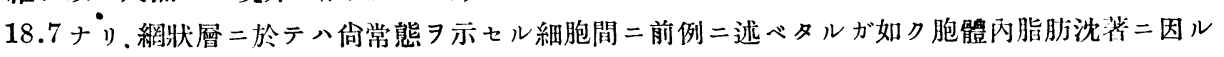
空胞 示七ル多數, 細胞 ナリ更ラ二胞體內單一，空胞 空隙ニ變セルアリ。核八略?正常構造ヨ保テルモノアリ. 或八空胞間二介在摩縮サレ或八細胞壁

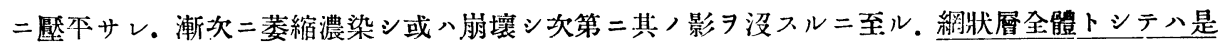
乙等脂肪沈著 $=ヨ$ リ各個ノ細胞腌大スル二從ヒ著シク其ノ容積

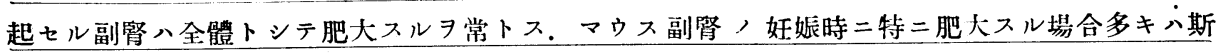

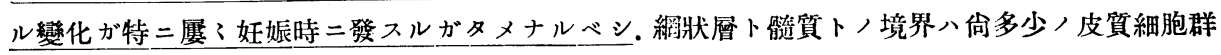

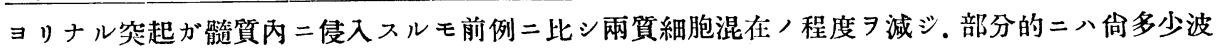
狀ヨ呈スルモ菲薄ナル結締織繊維 ヨナシ擴大セル血管腔 $コ$ 以テ隔テラル。細胞核へ形狀多ク入正圆. 大小種々ニシテ染色質ニ乏シ. 原形筫ノ「クローム反應八各細胞群ニョリテ異ナル。 


\section{第三章 第一編ノ事項二關スル文彫及ビ第二章ノ總括的觀察}

一般哺乳動物副婜, 構造八生後發有, 經過中及ビ完成後ノ正常構造二見ルモ各種動物二於テ

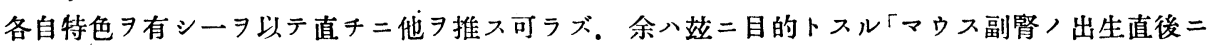
於ヶル組織的構造ヨリ雨後發有, 經過中二認メラルべキ變化ヨ觀察スベシ。

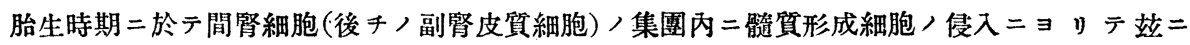
副腎, 形成 アリ。而シテ雨質細胞へ次第二分化スルト共二各自特有，細胞配列狀態 $コ$ 示ス $=$ 至ル。皮質細胞 八出生直後二於テハ未略、一樣ナル細胞ヨリナルモノトサル、モ次第三分化シ細胞ノ性狀及 ビ夫レ等ノ占居スベキ位置的關係二於テ區別シ得ベキ細胞層ヨ形成スルニ至ル。雨後ノ發有經過 ニ於テ之レ等細胞間二各消長點アリ。之レ等ノ點ハ殊ニ「マウス副腎,發育习觀察スルニ最モ重 要ナル事項ナリトス。

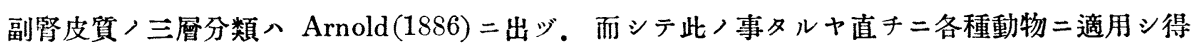
ベキニ非ラブ．例之ラッテ」二於テハ索狀層. 䌊狀層，境界甚ダ不明ナルニ對シ「マウス」ニ於テ 八制然タルモノアリ．而シテ絲迷層．索狀層境界八前省二於テ識別シ易キニ反シ「マウス」ニ於 テ困難ナル場合多キが如シ。

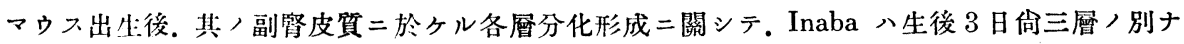
ク. 10 日ニシテ漸ヤク其，端緒习認ムベク． 30 日ニシテ明暸二三層习識別シ得ルトシ。增井。 田村八生後 5 日ニシテ網狀層細胞, 原基 7 見. 15 日ニシテ區別明暸ナリトス. 別所入出生直後 二於テ既二皮質二於テハ內外二層, 別 7 認入。生後 7 日ニシテ更ラニ綱狀層細胞, 原基 7 窺七 得クリトナスモ. Miller 八生後 3 週ニシテ初メテ網狀層习認ムベシトナス。

余八出生當日儿副腎二於テ．被膜直下，皮質細胞卜内方二於ケル夫レ等卜）間二明 暸ナル區別チ見 更ラ二髓質二直接セル皮質細胞中. 胞體小ニシテ境界明暸ナル一種 ノ細胞 認メ。恐ラク後チノ網狀層細胞タルベキモ)、原基ニ非ラズヤト思惟ス(第 265 號). 生後第 6 日ノモノ二於テハ細胞體内構造蜂案狀テ示セル索狀層細胞ノ髓質 二接近七ル部分二於テ八.上記網狀層細胞, 原基タルベシトナセシモノ更ラ二增加セ ルガ如シ．(第 283 號)．生後第 11 日二至リテ上記ノ細胞㿽了其ノ數み增シ．此ノ細 胞層キ以テ特別ノ一層尹形成七ルモ, ト見テ不可ナキガ如シ (第 282 號). 絲連層. 索 狀晋二於テ八增井. 时村八生後 $1-3$ 日ノモ; 二於テ. 索狀層細胞, 形態. 配列及ビ 類脂肪, 形態等八生長後,モノ二近ク。生後 15 日ニシテ絲踏層八成長後ノモノト同

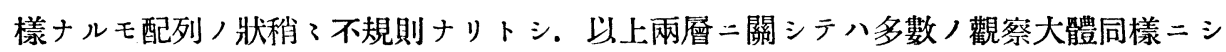
テ著シク相違七ル見解ナキガ如ク．余ノ見ルトコロニ於テモ生後 17 日一18日ノ所見 八雌雄ノ別ナク．即千絲毢層八外表被膜直下二於テ．此ノ被膜ヨリ分岐七儿結締織織 維八皮質內二進入增殖シ。或八毛細血管尹伴七。コ、二圓形或八楕圓形等ノ限界劃 シ. 此ノ內二數個ノ細胞核密接群在ス. 核八索狀層細胞二比シテ幾分小形且ツ染色質 
二富そ濃染スル傾向き示シ。細胞個々ノ境界不明ナリ．佾索狀層細胞，二比シ胞體內リ

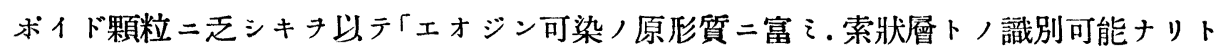
雖兩層, 境界ハ多クハ徐々二移行シ明確ナラザルキ㜞通トス. 佾時二外表被膜直下二

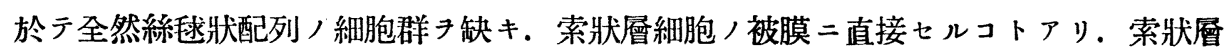
細胞ハ形態大且ツ個々相連ナリテ索狀キナシ. 各細胞索八髓質き中心トシテ放射狀ニ 配列シ。各索ハ毛細血管及ビ結締織繊維キ以テ互二隔テラル。細胞體內リボイド顆粒 二富 . 從テ特有ノ蜂巢狀構造キ示シ「エオジン可染原形質二乏シキキ以テ.絲逮層乃 至網狀層二比シ本層八著シク明暸ノ觀アリ。細胞體內リボイド顆粒ハ種々ナル生理的 狀況二因り增減スベク其ノ減ズルヤ先ヅ側, 緗胞之レチ失七漸次外方二及ブ. 故二 外觀常態キ示ス動物ニ於テモ。時二索狀層中內半部ハ圣然胞體蜂案狀構造キ示サベル モノアリ。細胞核八多ク八圓形. 染色質二乏シク胞狀キ呈シ一二固ノ核小體キ含ム。 本層及ビ絲述層細胞八内外, 刺戟二對シ後述スベキ網状層細胞，容易二反應ス几傾向 キ有スルニ對シテ頗ル安定ナルカノ感アリ。

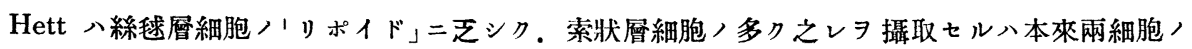

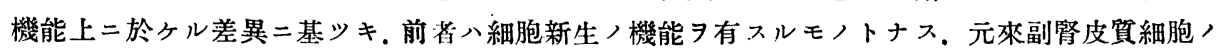
新生二關スル種子層トシテハ種々，見解アルモ絲㲑層ヨ以テ種子層トナスモノ多ク (Klylow. Starkel. Aschoff u. s. w.).此，部二新生セル細胞八漸次二內層二移動スルモノナリトス. Kolmer ハ「モルモット」二於テ絲践層索狀層. 境界部习種子層卜シ.Hett ハ「マウス」ニ於テ初生期二八皮

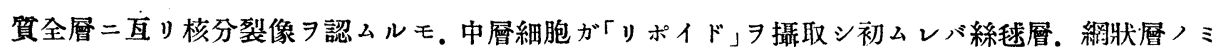

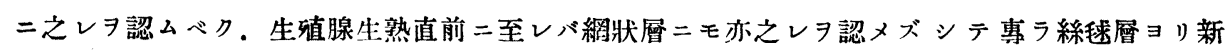
生スルモノトス. 別所八出生直後二於テ八核分裂像八皮質外帶二多》。1 15 日以後二於テ八索狀 網狀网層間二多數习認ム卜。

余ハ「マウス」ニ於テ胎生期間皮質留一樣ナル間腎細胞ヨリナレル場合二於テハ隨所 二核分裂像き見ルモ殊二外緣部二多キガ如ク生後 6 日二於テ八絲逮層二最モ多ク. 絲

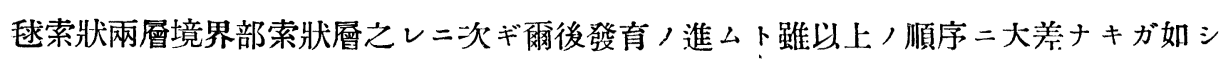
網狀層細胞新生二關シテハ後述スベシ。

網狀層八「マゥス」ニ於テ特色ヨ帶ビ. 殊二余, 觀察セル生殖腺機能卜副腎皮質卜，關係二於テ モ核心ヨナスモノナルヨ以テ少シク詳細二訅述スベシ. マウス副㹂皮筫二於テハ雌雄ノ別ナク 生後約 15 日ニシテ初メテ三層, 區別可能トナリ。網狀層へ徐々二其, 厚徑习增大シ。一定時期 二至りテ雌雄各了所見 $\exists$ 異ニスルニ至ルモ (壖井. 田村. 別所. Miller)、ラッテ」ニ於テハ雌雄 間著シキ差異ヨ認メズ. (Jackson. 松山) 唯ダ年龄入關係ニ於テ網狀層ハ幼弱ナルモ, 存在セ ザルモ年齢ノ進ム二從ヒ構造漸次明暸トナルト(藤田). 而シテ「モルモット」ニテハ.雄性ニ於テ本 層ノ厚徑雌性二優ルモノアリ(Kolmer. Takechi)。マウス」二就テ增井. 田村二依レバ. 生後 15 日 出現七ル網狀層、 30 日二至ル迄雌雄共二略了同一程度二存スレドモ。雨後各、發育ノ程度 
ニシ雄ニ於テハ 30 日以後八漸次二其, 厚徑习減少シ. 第 40 日二至りテ其ノ極度ニ達シテ僅か

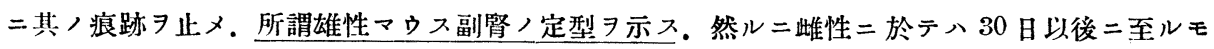

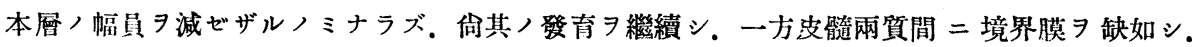

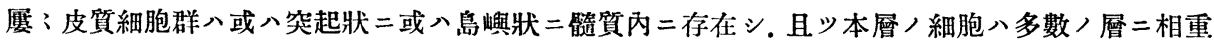
皘シテ著シキ厚徑ヨ示スモノアリト.別所モ同椂マウス副腎皮質, 生後定型ヨ示スニ至ル時期八

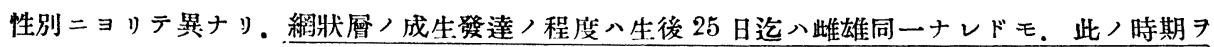
經過スレバ网考ノ間二相違ヨ來タシ。雄性、えレヨ媔點トシ漸次減少シテ生後 40 日二定型二達 シ. 雌雄八生後 50 日二發有，媔點二澾シ次第二減少シテ生後 90 日二雄性同樣，定型的幅員 $尹$ 示

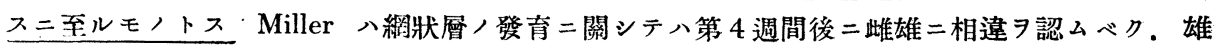
ニ於デハ之レョリ漸次二退縮ス. 而シテ其, 消失時期ニッイテハ個體ニョリ10日以内ノ動摇ア リトスルモ。生後 38 日ヨ經過シテ何網狀層ノ存在セシモノョ見ズ. 雌性ニ於テハ此ノ時期二至

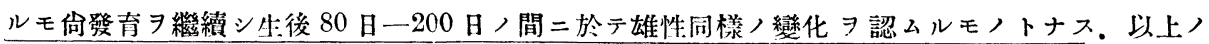
結果 7 比較スルモ網狀層，發有乃至退化二關シ其，時期二多少，差異アリトスルモ此雄性別二 因ル相遼习認ムルノ點ハ一致セリ。

余ノ觀察二於テハ表 I 二示スガ如ク. 雄性二於テハ生後 5 日一10日ニシテ僅カ二網

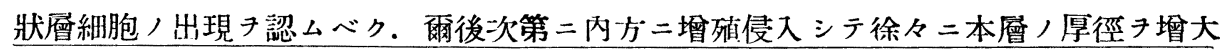
シ. 生後 20 日一 30 日二其, 厚徑最モ大. 次二漱次縮少シテ 35 日以後二於テハ皮髓境

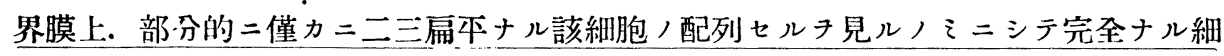
胞曆トシテ溜メラル、程度ノモノニ非ラザルガ如シ反之雌性二於ケル網狀層ハ生後20 日一30日，間八其，發育狀態略?雄性二等シク．雄性二於テ既二退縮スベキ 30 日一

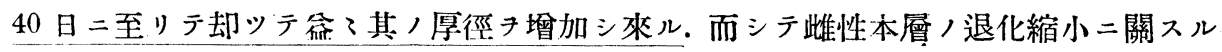
所見二就テハ余ノ觀祭必ズシモ上記交獻二一致七ザルモノアリ．例之生後 90 日ニシ テ本層ノ退縮極度二達三倠性同樣, 所見尹示スト云へルニ對シ。余ノ例二於ケル本均 龄87日ノモノ二於テ八絲十索: 網=10.0:7.8 示スガ如キ又 Miller，例二於ヶル 本均齡 131 日二於テ $29 \%$ 八網狀層沙失シ. $71 \%$ 八極度二變化七ル塽小ノ網狀層丹認 メシニ對シ. 余ノ例. 本均龄 143 日ノモノ 二於テ絲十索 : 網=10.0:10.6八厚鱼尹 示シ而シテ 8 例中 6 例二於テ八網狀厠細胞二退化的變性，像ナク．2例二輕度，變化 フ認メタルノそ(表 II)。

網狀層細胞及ビ其ノ退行的變化. 索狀層細胞索ノ配列. 走行整然タル二比シ. 網狀 層細胞八配置不規則. 從テ細胞間二存在スル毛細血管及ビ結締織緎維ノ走行モ亦之レ

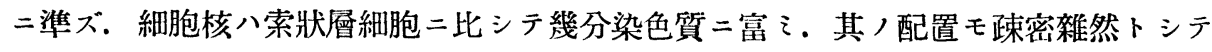
後者ノ整然タルニ比スベクモナシ. 各個胞體ノ境界概子不明ニシテ胞體內蜂巢狀構造 ヨ示サズ.エオジン可染原形質二富そ．脂肪染色ニヨリテ極メテ微細ナル「リホイド 顆粒少量尹認ムルニ過ギズ. 索狀層卜ノ境界ニ於テ八. 周圍細胞二比シ特殊ノ細胞ヨ、 


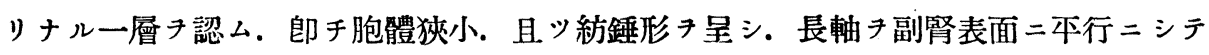
立列シ．僅カ二二三列二過ギズ．弱廓大ニテ之レチ檢スレバ兩層間二青色ノ一線タ劃

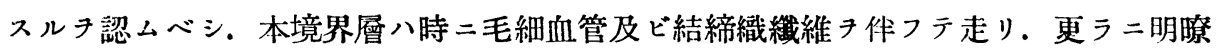
二索狀. 網狀兩層, 境界‡形成スルコトアリ. 殊二成熟䧳及ビ去勢後/雌. 雄二於テ 多々認メラル，網狀層卜髓質卜ノ境界部八前者出現八初メョリ兩質細胞混在シ。漸次 二形狀不規則ナル多數, 皮質細胞突起八䯕質內二侵入スルト共二。皮質細胞群八岛嶼 狀二骨遀質內二散在入。雄二於テ八生後 30 日一 40 日二於テ網狀層細胞八原形質濃縮污 染シ形狀不規則トナリ。或ハ樎小シ或ハ不明トナリ。核亦同樣二萎縮破碎シテ桷次二

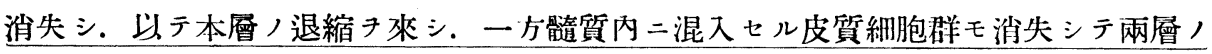
境界明暸トナルト共二。斯クノ如ク實質細胞ノ退化消失スルニ從七殘存セル結締織織 維. 毛紐血管等ハ互二壓縮サレテ皮髓兩質間二境界膜キ形成スルニ至り網狀層細胞八 僅カ二境界膜上二三三列ノ狹小扁雨ナル細胞トシテ殘存スル二過ギズ. 部分的二八全 然之レチ缺如シ。索狀層細胞八境界膜二直接スルニ至ルコトアリ。

雄性マウス」二於テ皮髓雨質間二於ヶル境界及ビ境界膜二關シテ．Miller 八雄性ニテハ緗狀層 ノ消失スルヤ。皮髓雨質間二被膜出現スルモノトシ. Inaba 八雌雄ヨ明記セザルモ生後 30 日二

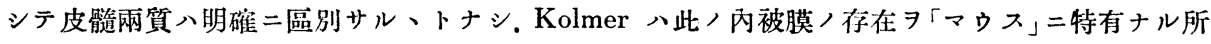

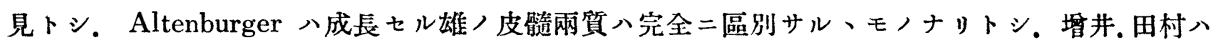

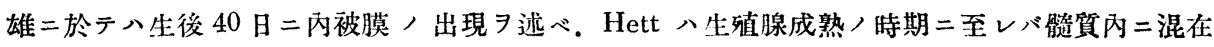
スル皮質細胞ヨ認ムルヨ得ズトシ. 別所八雄二於テハ生後 40 日. 雌二於テハ生後 90 日二內被

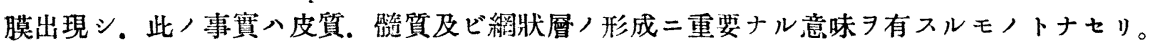

雌性二於ヶル正常ナル網狀層細胞ノ性狀八雄二異ナラズ. 索狀層卜ノ境界八雄二比

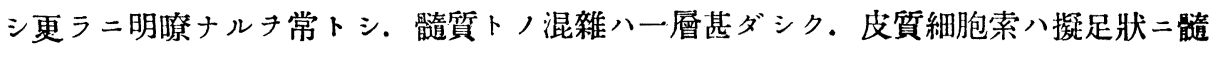
質縱横二貫通ス. 網狀曆細胞ノ退化的變化二關シテハ雄ニ於テ常二生後 30 日-40 日ニシテ退縮スルニ對シ.雌ニ於テハ此ノ時期ニ至ルモ向增殖ノ傾向キ示スモノアリ. 余／觀察セル範圍二於テハ雄性二於ケルガ如ク其，退縮スル二特定ノ時期き（例之文 獻二於ケル生後 90 日ト云へルガ如キ). 確定スル能ハザリキ. 而シテ本緗胞ノ退化時 期二於テ Miller 八處好マウス」ニ於テハ生後 30 日一 87 日二初・リ. 生後 83 日後二 於テ退化像 (即千胞體內, Vacuolization) チ示サ・゙例テ見ザリシト雖. 余ノ例二於

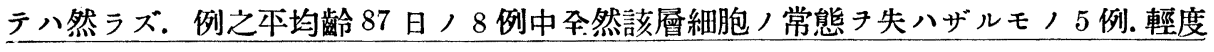
二脂肪沈著尹來タセルモ/ 1 例. 中等度ノモ/ 1 例高度ノモ/ 1 例 數工。(表 II )

雌性二於々ル網狀層細胞, 退行的變化八二樣,機轉ニョリテ行ハル。一ツハ雄性， 場合卜同樣. 核八萎縮シ或八破壞 シ胞體内原形質モ同時二濃縮. 污染シ次第二退化消 
減スルモノニシテ、他ハ「マウス雌性二特有ナル變化ニシテ雄ニハ之チ認メザルモノ ナリ．郎千䋞胞艚内二脂肪沈著キ來スモノニシテ退化，初期二於テ八胞體内微細ナル 蜂巢狀構造 示スモ次第二融合增大ス. 脂肪染色ニョリ初メ微細ナル脂肪顆粒八漸次 二增大スルチ㤎ムルキ得べシ. 斯ク脂肪化セル胞體內ニ於テハ. 初メ佔核常態尹保テ ルモノアリ. 或八空胞間二介在㕓縮サレ或八細胞壁二厴本サレ次第二萎縮崩壞シ遂二 八其ノ殘骸尹止メザルニ至ルモノアリ。斯, 如ク脂肪化二因ル空胞モ次第二融合增大 シ或八空胞壁破裂シ二三個相合シテ不正形ノ大ナル空隙二變セルモノアリ。之等空

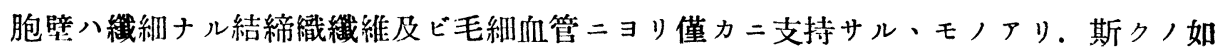

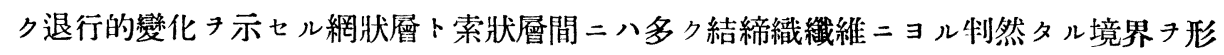
成シ.上記八空胞ノ次第二泞減スルニ從七網狀層八渐次二縮小スルモ。空胞壁丹形成 セル支柱結締織纎維及ビ毛練血管等八殘存シテ互二厴縮サレ. 上記境界壁卜相共二皮

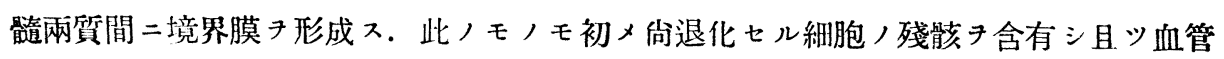
二富メル影粗ナル繊維性組織ヨリナルモ次第二結締織, 細狹ナル條片トナル。網狀層 二於テ林變化, 起ルヤ多ク中央帶二初、リ. 次第二内外二進么. 時二索狀層卜ノ境界 部ニ於テハ常態キ保テル細胞數層き殘留スルコトアリ。

以上記述七几網狀層細胞儿變化入恰力モ生殖腺成熟，時期二二致ス儿，事惯八雨者

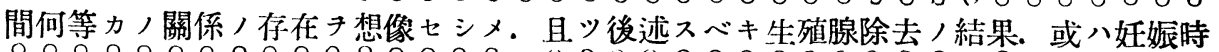

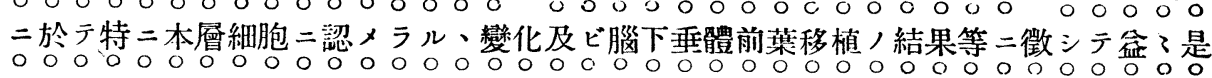
等们互關係, 密接ナルモ,アルべキチ思ハシム. 而シテ雄二於テハ生殖腺機能状態比 較的簡單ナル二比シ雌二於テハ必ズシモ然ラズえレ副腎二及ボス影響. 從テ夫レ等， 結果トシテ副腎二現ハルベキ形態的變化二至リテモ雌二於テハ雄ニ於ケルガ如ク．若 ク單純ナル能バザル一面ノ理由タルベシ. 佾本變化二關シテハ更ラ二後述スべキ妊娠 時二於ケル副腎, 變化丹觀察スルニ當りテ考虑スルコトアルベシ。

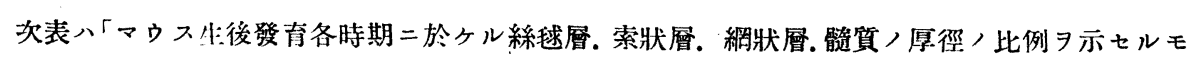

(表 I 雄)

\begin{tabular}{|c|c|c|c|c|c|}
\hline 生後經過日㩯 & 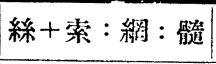 & 絲十索: 網 & 生後經過日數 & 絲十索：網：㖪 & 絲+索：網 \\
\hline 1日一 5 日 & $7.3: 0 \quad: 7.6$ & $10: 0$ & 21 日一-30日 & $11.2: 7.5: 15.0$ & $10: 6.7$ \\
\hline 6 日-10日 & $6.4: 0.6: 7.9$ & $10: 0.9$ & 31 日-35日 & $13.9: 2.9: 15.2$ & $10: 2.1$ \\
\hline 11 日一-14日 & $7.4: 0.6: 9.0$ & $10: 0.8$ & 35 日一 -40 日 & $|13.6: 0: 12.2|$ & $10: 0$ \\
\hline 15 日一-20日 & $10.7: 3.4: 13.5$ & $10: 3.1$ & & & \\
\hline
\end{tabular}


(表 II 雌)

\begin{tabular}{|c|c|c|c|c|c|}
\hline 生後經過日數 & 絲十索：網：髓 & 絲十索 : 網 & 生後經過日數 & 綵十索：網：䯕 & 絲十索：網 \\
\hline 14日一 20 日 & 8.1: $1.6: 12.1$ & $10: 1.9$ & 84 日一 -91 日 & $13.9: 9.3: 18.9$ & $10: 6.7$ \\
\hline 21 日一一 30 日 & $12.1: 6.7: 13.1$ & $10: 5.5$ & 92 日 -100 日 & $12.2: 11.2: 20.3$ & $10: 9.1$ \\
\hline 31 日一 40 日 & $14.7: 7.4: 15.9$ & $10: 5.0$ & 101 日一-105日 & $13.9: 12.2: 16.7$ & $10: 8.9$ \\
\hline 41 日一 55 日 & $12.2: 10.4: 14.5$ & $10: 8.9$ & 107 日-124日 & $14.5: 13.4: 18.6$ & $10: 9.2$ \\
\hline 56 日一 65 日 & $13.8: 13.4: 17.8$ & $10: 9.4$ & 125 日一-168日 & $16.2: 15.2: 18.9$ & $10: 9.3$ \\
\hline 66 日一 83 日 & $14.3: 10.4: 16.6$ & $10: 7.2$ & & & \\
\hline
\end{tabular}

（表 III 雌）

\begin{tabular}{|c|c|c|c|c|c|c|c|}
\hline 生後經過日數 & 平均錀 & - & + & H & H & $x$ & $\begin{array}{l}\text { 動物 } \\
\text { 總數 }\end{array}$ \\
\hline 23 日一 30 日 & 26 日 & 7 & 0 & 0 & 0 & 0 & 7 \\
\hline 31 日一 40 日 & 34 日 & 6 & 0 & 0 & 0 & 0 & 6 \\
\hline 41 日一一 55 日 & 46 日 & 5 & 2 & 0 & 0 & 0 & 7 \\
\hline 56 日一 65 日 & 63 日 & 6 & 1 & 1 & 0 & 0 & 8 \\
\hline 66 日一 83 日 & 72 日 & 6 & 1 & 0 & 1 & 0 & 8 \\
\hline 84 日一 91 日 & 87 日 & 5 & 1 & 1 & 1 & 0 & 8 \\
\hline 92 日一-100日 & 95 日 & 1 & 4 & 3 & 0 & 0 & 8 \\
\hline 101日一107日 & 102日 & 7 & 1. & 0 . & 0 & 0 & 8 \\
\hline 108日-124日 & 113日 & 5 & 2 & 1 & 0 & 0 & 8 \\
\hline \multirow[t]{2}{*}{125 日一-168日 } & 143日 & 6 & 2 & 0 & 0 & 0 & 8 \\
\hline & & 54 & 14 & 6 & 2 & 0 & 76 \\
\hline
\end{tabular}

表四八雌正常マウス」二於テ幼弱時ヨリ成長後ニ至ル各時期

二於ヶル網狀層細胞ノ變化ノ狀態习示セルモノナリ。

$(-) \cdots$ 網狀層細胞二變化ナキヨ示シ $(+) \cdots$ 輕度二綱狀

層細胞二脂肪沈著 $コ$ 來タセルモ， (†) $\cdots$ 中等度二同上，

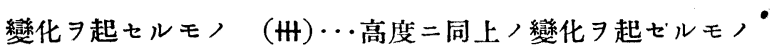

$(\times) \cdots$ 網狀層, 退縮セルモノヨ示ス

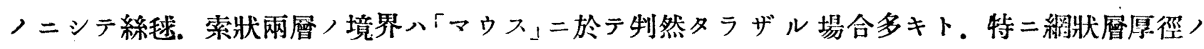
增大及ビ縮少ヨ觀察スル場合多キが故二。强イテ兩層习區別計測スルノ必要少ナキヨ以テ雨者 ヨ合シテ他層卜，比較习示七リ。侗本表二於ヶル動物數ハ雄性 60 . 雌性 86 ナリ。而シテ雌. 雄 ニ於テ八生後 15 日以前二メ大體各層發有, 程度兩者大差ナキヨ以テ之レヨ區別セズ。 


\section{第二編 雌雄マウス生殖腺ノ種々ナル機能狀態二因ル

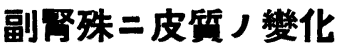 第一章 マウス」ニ於テ生殖腺除去ノ副衉皮罂二及 ボス影帮}

\section{第一項 文 獻}

生殖腺機能卜副腎皮質間二密接ナル關係, 存在スルコトハ.之レヨ文獻ニ徵スルモ疑ナキガ如 シ. 而シテ生殖腺機能 7 除外シ。結果トシテ副靔皮質二意起七ラルベキ變化 7 觀察シ以テ兩者 間, 關係ヨ探究セントスル八㕍 了用ヒラレタル手段ナリ。Aschoff 八人類二於テ其, 生殖機能 存スル期間內種々ナル狀況, 變化. 殊二妊娠二因りテ副腎皮質, 影響习蒙ムルコト磪賽ナルヨ以 テ去勢後二於テ何等カノ戀化习認ムベキハ期待シ得ベキコトナリトシ. Schenk 八家鬼二於テハ 雌雄 問ハズ共二常態ニテハ認メラレザル程度ノ網狀層が. 去勢後明暸二出現シ從テ副腎皮質ノ 肥大ヨ來スヨ認メ.卵巢機能中絕二因ルモノナルベシト言ヒ. Kolde モ同樣/變化 シモ「モルモット」ニテハ然ラプトセリ. Remon et Delille ハ家兔二. Theodosieff ハ犬ニ於テ卵

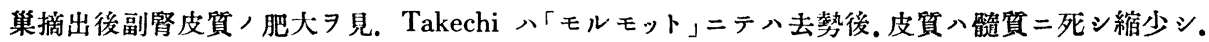
更ラ二全皮質中二特二網狀層ノ縮少 $\exists$ 見シト。藤田入雄性ラッテ」ニテ去勢後甞狀層, 增生二因 ル皮質, 擴張 7 認メ. 網狀層, 發育艮好ナルハ去勢二關係ナシトシ. 畑井モ同樣/所見 7 認メタ

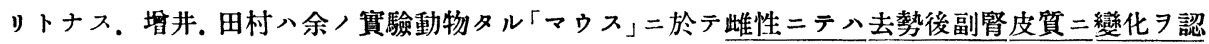
メズ. Miller 八同ジク雌成熟マウス 12 例 ヨ去勢シ 13 日-33日後ノ所見ニョレバ網狀層(彼レ ノ所謂 X-zone) 二於テハ常態二認メラルぶキ該層細胞, 退行的變化 (Vacuolization) =影響 ボサズト Altenburger ハ「マウス」ニ於テ（彼レハ雌雄ヨ明訅セザルモ彼レノ所見ニョリ恐ラク雄 性ヨ意味スルモノナルベシ). 生後 3 週二去勢セル場合皮質ノ擴張

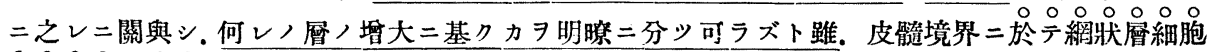

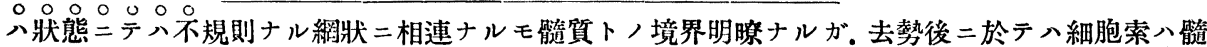

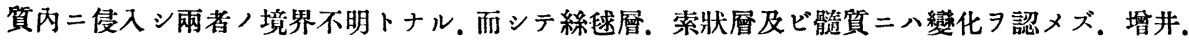
田村八同樣雄性マウス 殆ド缺如セル網狀層が急二增殖肥厚シ來リ䧳卜同一程度二發達スルニヨル: 絲毢層索狀層二八戀

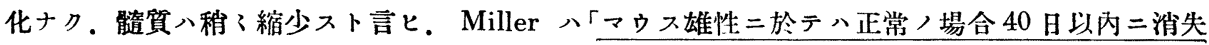
スベキ網狀層ハ去勢後少ナクトモ4 ケ月間八存在スト云へリ。

\section{第二項 雄性マウス」ノ選定及ビ試驗二關スハー般的注意}

本去勢試驗 目的トスルトコロハ「マウス」ニ於テ.生殖腺機能 7 全然裝失セル場合二副腎殊二 皮質細胞ノ之レニ對シテ如何二反隹スルヤヨ觀察センが䉆ナリ．雄性マウス」ニ行へル去勢試驗 動物數ハ 46 ニシテ全部飼養中出生セシメ. 其ノ出生時日ノ明暸ナルモノ、ミヨ使用セリ。對照 トシテハ各例必ズシモ之レヨ設ケズ，何トナレバ雄ニテハ生後 40 日ヨ經過スレバ副腎ノ組織的

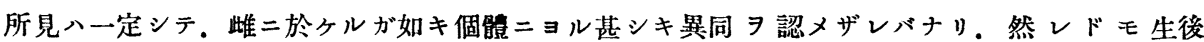
40 日以前二武驗動物 7 檢査スル場合二八同腹ノ對照 7 設ク。去勢時期ハ生後 22 日ョリ109日 
至ル。即チ生後 40 日ヨ略了雄マウス」生殖腺成熟期卜スレパ。份ホ未熟ナルモノ及ビ成熟後 ノ種々ナル時期ニ於ヶル去勢ニ因リテ苾起セラルベキ所見ノ相違习觀察セシが篇メナリ。而ンテ 去勢時ヨリ檢查迄, 經過日數八去勢後第 20 日ョリ第 271 日二至ル種々ナル時期ニ之レヨ觀察 シ. 去勢後, 經過日數, 差ニョリテ起ル所見ノ相違ヨ見ルコト、七り。

\section{第三項 雄性マウス去勢後二於ケル副腎殊二皮質ノ組}

織的構造

本項ニ於テ各種，場合二於ヶル詳細ナル所見，記述、媔雜ニ互ルモノアルョ、以テ媇ニ或ル二 三八場合ノミヨ選ビテ之レヨ記述シ次項ニ於テ更ラニ詳細二總括的ニ之レ等 觀察スルコト、 주

雄性マウス生後20日二去勢シ 67 日 經過七ルモ，、副腎，組織的所 見 (第 592 號)

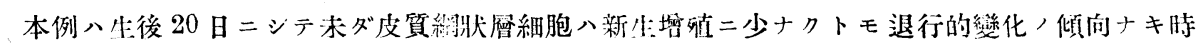

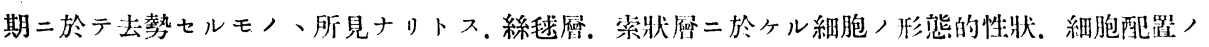

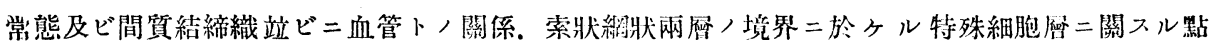

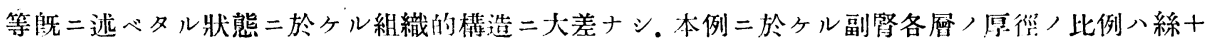

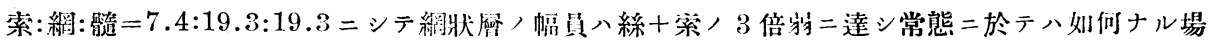
合二於テモ斯ル比例

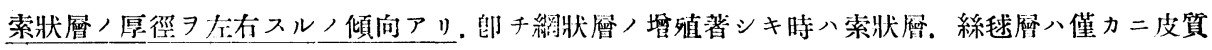

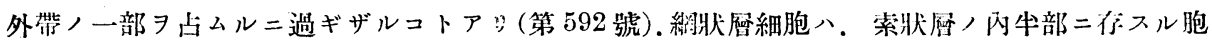
體內蜂策狀構造鮮明ナラザル細胞二類似、相連ナリテ猄狀ヨ形成スルモ。其, 走行不規則 ニシテ 各索ノ結合密ナラズ. 毛細血管及ビ結締織織維 テ疎密雜然タリ、網狀層卜䯕質卜，境界二八正常成長雄二見ルが如キ。境界膜习缺如シ皮質細胞

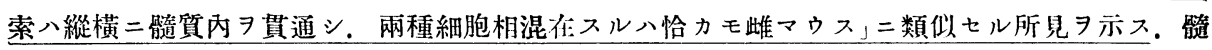
細胞八核ノ形狀. 大キサ略了絧狀層細胞ノ夫レニ類スルモ染色質ニ乏シキへ. 原形質ノ染色性 異ニスルニヨリ容易二混交セル雨種細胞习識別スルヨ得ぶシ。

生後 64 日ノ雄マウス」ヨ去勢シ 80 日 見 (第 626 號)

本例八前例卜異ナリ生後 64 日 7 經過セルモノナル ル境界膜 形成シ絴狀層細胞トシテ八境界膜上二僅力二其入痕跡习殘セル狀態ニアルモノ 去勢习施シタルモノニシテ. 去勢後 80 日ヨ經過セルモ,、所見ナリ。副腎各層厚德，比例八絲

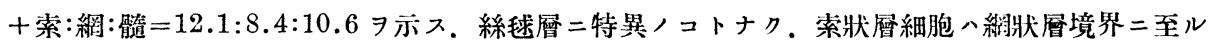

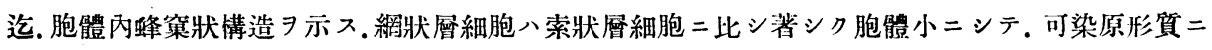
富ミ核ノ配置密ナル メテ不規則ナリ。絴狀層二於テハ部分的ニ八辛フジテ各個細胞, 境界习認メ得汇モ核ノ配置疎 密極メテ不規則ナリ. 本例二於テハ僅力二痕跡的二內被膜上二殘存セル網狀層細胞八去勢入結果

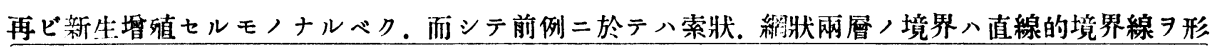


成シ區別明暸ナルモ。本例二於テ然ラザル所以八前例ニデ八新生網狀層細胞八專ラ膸質內二堽殖

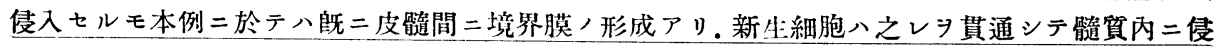
入スルコトナク，反對二索狀層側二向と，其，細胞索間二侵入檑殖スルモ各細胞群，增殖程度一

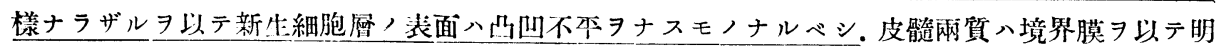
暸二區别サレ雨萑ノ混交スルモノナシ。

\section{第四項 前項二關スル總括的觀察}

雄性マウス副掔皮質網狀愿細胞八生後 30 日一40日二於テ次第二退化消隇シ。各細

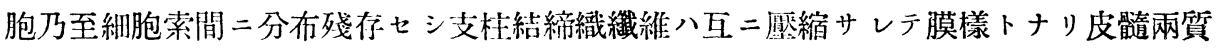
間二介在三兩者ノ境界膜チ形成ス。斯ル狀態き成長雄マウス副婜ノ定型トナスモノナ ルガ. 此 狀態二達スル時期八恰カモ雄性生㱠腺成熟八時期二一致スルモノナリ. 然

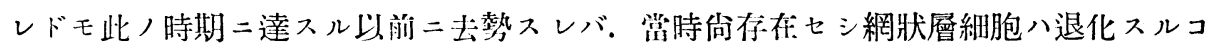
トナク. 却テ更ラ二新生檑殖スルノ倾向チ示シ。一方該細胞群八恰カモ擬足狀二骨遀質

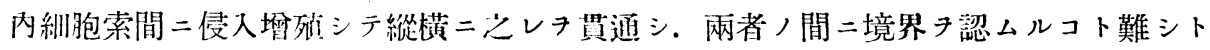
ス然ル二他方索狀層側二於テ八网層間二存スル境界き貫通シテ該層队二增殖侵入スル

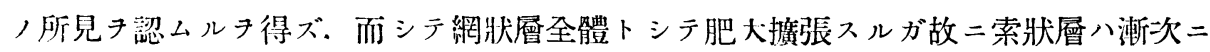

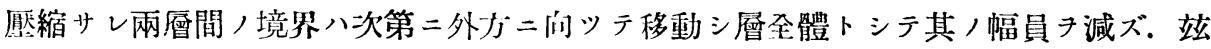
二新生增殖スル網狀層細胞八境界層二屬スル紐胞二比シテ八胞體大キク且ツ胞體内脂

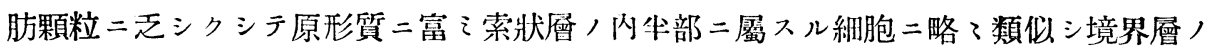
存在ニヨリテ僅カ二兩者き區別シ得ルコトアリ. 斯ク增殖セル緗胞八相當長期間此， 狀態子保ツモ逐二八髓質内二混在七ル細胞ハ次第二退縮消失シ。皮髓境界ハ可ナリ明 暸トナルモ正常, 場合二於ケルガ如キ明暸ナル队被膜き形成スルコトナキガ如ク. 且 ツ該層緗胞二於テハ特篗スベキ程度ノ退化モ認メラレズ. 第 573 號八去勢後 271 日タ 經過セルモノナルガ各曆厚徑ノ比例八絲十索: 網: 髓=11.8:4.9:15.0 キ示スガ恐ラ ク最後迄此ノ狀態キ保有スルモノニ非ラザルカ. 家鬼去勢, 場合. 網狀層二同樣ノ變 化認メタル Schenk 八生殖腺成熟後,去勢, 場合八幼弱ナルモノニ於ケルヨリ遙 カ二明暸ナル變化キ認ムルキ得タリトスルモ。マウス」二於ケル余，場合二於テハ事 情異ナルガ如シ. 即于生後 40 日チ經過シ既二雄性副腎, 定型 チ示セルモノニ於ケル 去勢, 結果八前述, 場合卜異り內被膜ノ外側二直接シテ僅カ二殘存セル網狀層細胞八 新タ二增殖シ初マルモ前述, 場合二比シ極メテ徐々二。然力モ是等增殖細胞八索狀層 内二向ツテ進之。恰カモ皮髓境界膜, 存在ニョリテ其, 進路キ妨ゲラル、カノ如ク之 レチ貫通シテ髓質內ニ侵入スルコトナシ. 索狀層內二增殖侵入セル各細胞群ハ夫レ等 
ノ增殖進行程度必ズシモ一樣ナラザルベク從テ立二形成サル、網狀層ノ表面二凸凹不 本. 不規則ナルキ普通トシ。索狀層卜ノ間二前者ノ場合二於ケルガ如キ兩層き明暸二 區別シ得べキ境界層き形成スルコトチ普通トス。茲二增殖セル細胞八前述七ル場合卜 同樣胞體內脂肪顆粒二乏シク原形質二富メルガ故二．相隣接セル索狀層細胞，胞體內 蜂菓狀丹示セルモノニ比シテ明暸二兩者子識別スルコトチ得ベシ. 皮髓境界二於ケル

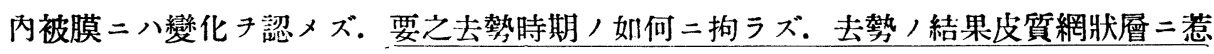
起ャラル心゙キ變化ハ大體兩者同樣ナルモ其，程度二强弱アルハ一般動物去勢試驗二於 ケルガ如ク幼弱時二行ハレシ去勢，第二性徵二及ボス影響八成熟後二於ケルモ，二比 シテ甚大ナル，事實二一致スルモノナルベシ。次表八同腹 4 匹ノ雄性マウス」二於テ去 勢時, 齡卜增殖七シ網狀層卜ノ關係丹示スモノニシテ年齢增加卜共二練胞增殖程度八 互二相反スル關係ニアルモノトス。

(表 IV 雄)

\begin{tabular}{|c|c|c|c|c|}
\hline 動物番號 & 去勢時齢 & \begin{tabular}{|l|} 
去荔後經 \\
過日數
\end{tabular} & 絲十索：網 & 皮質：夦質 \\
\hline 第 351 號 & 生後29日 & 30 日 & $10: 6.0$ & $10: 9.4$ \\
\hline 第 352 號 & 生後35日 & 30 日 & 10 & $10: 7.8$ \\
\hline 第 354 號 & 生後42日 & 30 日 & $10: 4.1$ & $10: 9.7$ \\
\hline 第 355 號 & 生後55日 & 30 日 & $10: 2.7$ & $10: 11.3$ \\
\hline
\end{tabular}

新生網狀層厚徑, 大小が去勢後, 經過日數二關係习有スルハ勿論想像サルベキコトナレドモ. 次表八是等ノ關係习示セルモノナリ。郎手同腹 4 匹ヨ生後 64 日二去勢シタルモノニシテ第 627 號八同腹ニシテ無處置,モ,. 生後 144 日 7 經過セルモノナリ。本表ニ於ケル去勢試驗 7 生後 64 日二行へル理由八未成熟動物去势, 場合二八當時存在セル網狀層細胞, 更ラ二堽殖习續クル モノナラバ新生細胞層卜去勢後, 經過日數卜ノ關係习觀ルニ便ナラズ. 戌育マウス」ノ場合二於

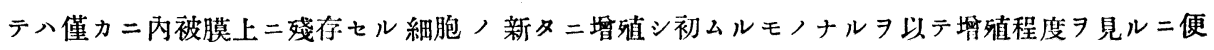
ナリトス。

(表 V)

\begin{tabular}{|c|c|c|c|c|}
\hline 動物番號 & 去勢時齢 & 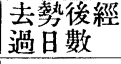 & 絲十索：網 & 皮質：髈質 \\
\hline 第 496 號 & 生後64日 & 20 日 & $10: 4.6$ & $10: 12.8$ \\
\hline 第 542 號 & " 64 日 & 40 日 & $10: 5.2$ & 10. 9.0 \\
\hline 第 576 號 & " 64 日 & 60 日 & $10: 6.6$ & $10: 9.7$ \\
\hline 第 626 號 & " 64日 & 80 日 & $10: 6.9$ & $10: 5.1$ \\
\hline $\begin{array}{c}\text { 第 } 627 \text { 號 } \\
\text { 生後 } 144 \text { 日 }\end{array}$ & I & $\zeta$ & $10: 0$ & $10: 14.0$ \\
\hline
\end{tabular}


上表ニヨリテ去勢後, 經過日數二相當シテ漸次二網狀層，厚徑，增大スル傾向キ認 ムルタ得ベシ。

要之雄性マウス副腎皮質網狀層細胞ハ生殖腺成熟時期二相當シテ退化ノ傾向 示ス モ. 幼弱時二其，生殖腺フ除去スレバ成熟時期二達スルモ該細胞八退化セズシテ幼弱 時ニ於ヶルガ如ク少發有增殖キ繼續スル，事實ハ。事ノ經過八暫ラク不問トスルモ生 殖腺機能二對シテ該細胞機能ガ拮抗性尹有スルカ. 或八兩者/機能互二代償的ノ意味 尹有スルモノナリヤ俄カ二斷ズ可ラズトスルモ生殖腺機能ガ網狀厤細胞ノ消長 左右 國八該䋛胞ノ有スル機能二何等カノ關係有スルコト八想像シ得ベキコトナリト ス. 份該細胞, 生殖腺二對スル關係八恰カモ胸腺, 生殖腺二對スル態度二類似スルモ ノアルガ如シ。去勢試驗中單二一側ノ殬丸丹除去セル場合八網狀層細胞ニ及ブ影響き 認ムルタ得ザル八圅丸ノ或ル程度ノ機能低下八網狀層細胞ノ退縮二影響き及ボシ得ザ ルモノカ. 或八他側二於テ略 了正常ノ程度二機能キ代償セルモノナルベシ。

\section{第五項＼cjkstart檢査材料トシテ雌性マウス選定ニ關スル泩意}

本試驗二使用セル動物數ハ 41 ニシテ是等動物ノ選定二關スル注意ハ雄性ノ場合二同ジ，而シ

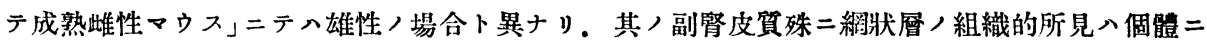
ヨリ異同甚シキモノアルヨ以テ. 各例二必ブ同腹ニシテ發青狀態同樣ナル對照

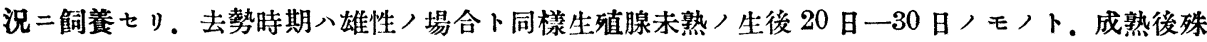

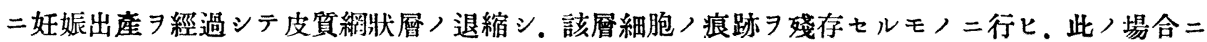
於ヶル該細胞ノ態度 ヨ觀察セリ。

\section{第六項 雌性マウス去勢後ノ副腎特二皮質ノ組織的所}

$$
\text { 見二關スル總括的観察 }
$$

雌性マウス.去勢後，副腎皮質綱狀層，組織的所見二關シテ. 大體雄性去勢後，增殖肥大セル該 層, 所見及ビ正常成長雌, 該層細胞體内二脂肪沈著习見ザル場合, 所見卜大體同樣ナルヨ以テ.

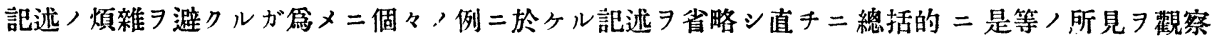
スベシ。

雌マウス生殖腺成熟前二可及的早期二兩側卵㮐丹摘出スレバ，雄性／場合卜同樣去 勢當時存在七シ網狀層細胞八更ラ二新生增殖き繼續シ。一方骨遀質内二侵入スルト共二

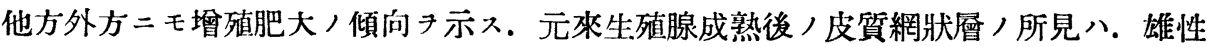
ニテハ生後 40 日チ過グレバ皮髓兩質ノ境界八內被膜ノ形成ト共二明暸トナリ。網狀 層細胞ハ退化シテ僅カニ其ノ痕跡テ殘ス二過ギザレドモ。雌性ニテハ此ノ時期二達ス ルモ．大體二於テ雄性同樣ノ退化的傾向キ示サズ．故二去勢後ノ副腎皮質, 變化モ雄 
性ニテハ對照動物トノ比較顯著ナリト雖䧳性ニテハ然ラズ. 之レ從來ノ文獻二於テ. 卵巢摘出八副腎二影響キ及ボサズトサレシ一面)理由二非ラザルカ(增井. 田村. Miller).成長雌マウス副腎皮質網狀層二關シテハ前述七シガ如ク動物/龄及ビ發育狀

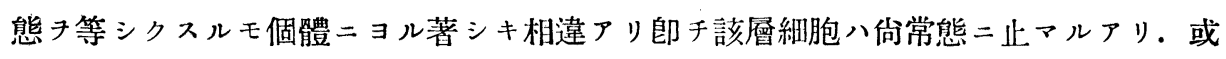
八成熟此倠マウス」二特有ナル本層細胞體內二脂肪沈著尹來タセルモノアリ.或八此ノ狀 態ヨリ更ラニ進ンデ退化的變化キ遂グルモノアリ。或八胞體门脂肪沈著キ見ズシテ核 八萎縮崩壞シ次デ細胞ノ死隇キ來タシ漸次二該層ノ縮小ォ見ル場合アリ。然ル二去勢 後ニ於テハ該細胞八退化ノ傾向キ示スコト少ナキキ晋通トシ. 殊二常態特二弤娠時二 屢了見ラル、上記胞體內脂肪沈著ニョル退行的變化，如キハみレチ認ムルチ得ズ.

故二對照二於テ著シキ退化的所見き示ス場合二於テハ兩者ノ相違朋暸ナリト雖(第455

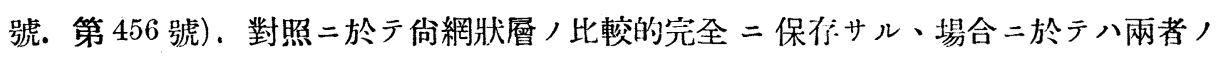
相違キ看取スルコト困難ナルガ如シ (第 410 號. 第 411 號). 然レドモ詳細二是等キ比 較觀察スル時ハ去勢後ニ於テハ網狀層細胞ハ增殖的傾问キ示スコトキ認メ得ベク且ツ 該層厚徑二於テ兩者間二多少ノ差き認ムルコトチ得ベシ. 表 VI 二於ケル對照八同腹 ニシテ兩者完全二同一ノ狀況二飼育シタルモノ。而シテ對照中該絸胞體内二脂肪沈著

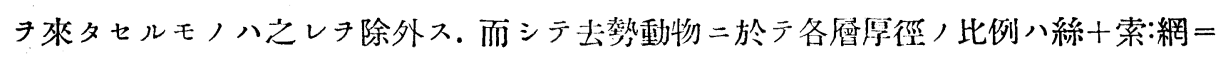
10:11.9ナル二對シ。對照ニテハ絲十索:網 $=10: 6.7$ チ示ス. 郎于去勢動物二於テ八該

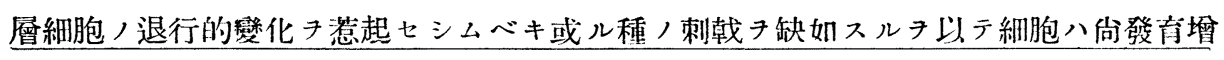
殖スベキモ正常動物ニテハ其，發育中＼cjkstart或ル時期一例之生殖腺成熟期一二達シテ们等 カノ刺戟キ受ケ該細胞ハ退化的倾向キ現ハシタルモノト思考スルチ得ベシ。

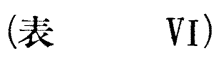

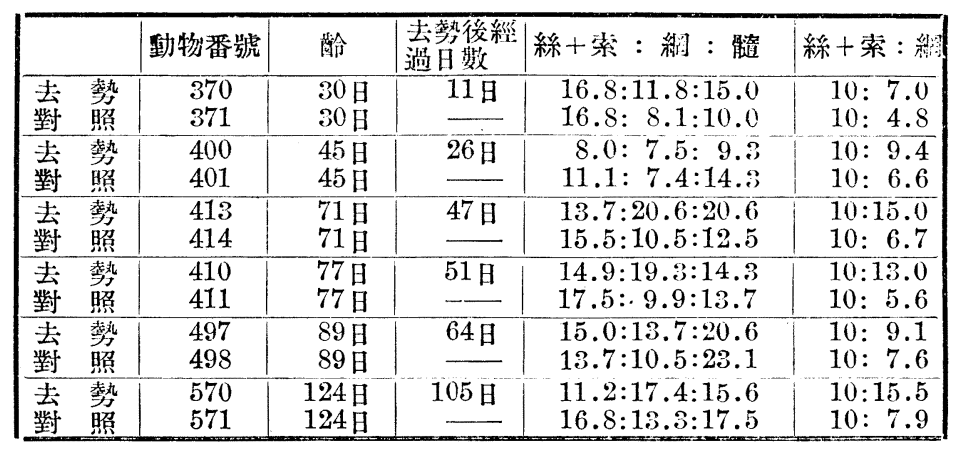

前述七ルガ如ク此倠マウス」ガ妊娠出產キ經過スレバ屡了網狀曆細胞ハ退行的變化二 陷ル。從テ網狀層八退縮三皮髓間二境界膜き形成三網狀層細胞八僅力二其, 痕跡キ殘 
存スルニ過ギザル八成長雄性ノ場合二類似スルモノアリ. 而シテ去勢ノ是等殘存セル 細胞二及ボス影響モ略、雄性同樣ニシテ去勢後是等細胞八徐々二增殖き初ムルモ。雄 性ノ場合卜同樣. 新生緗胞八內被膜尹贯通シテ骨遀質内二侵入スルコトナク. 索狀層細

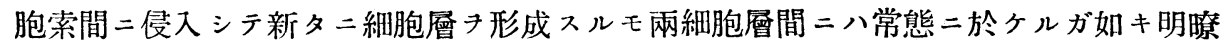
ナル境界チ存入ルコトナキチ以テ．僅カニ夫レ等緗胞ノ性狀ニョリテ兩者テ區別シ得 ベキモノトス。

\section{第二章 マウス」ニ於テ妊娠ノ副腎特ニ皮啠ニ及ボス影響}

\section{第一項 文 獻}

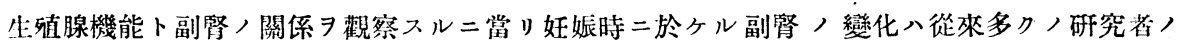

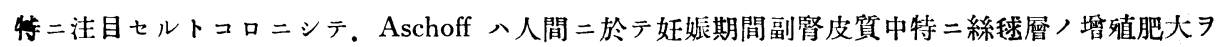
認メ. Sambalino モ阔ジク人間ニテ網狀層，明暸二出現スルコト及ビ該嬮細胞體內二色素顆粓

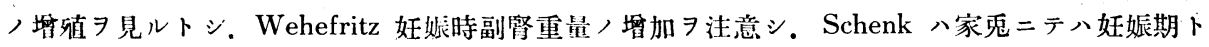

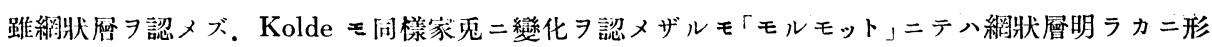
成サレ且ッ本原細胞體内二色素顆䊉出現シ索狀層細胞二八空胞形成 7 見. 而シテ雨種動物二於久 ル斯ル相暴八娃娠期間，長短二因ルモノナルベシト.. Gottschau 八家鬼二於テハ妊娠卜共二

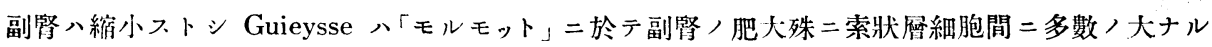

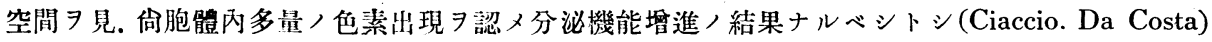

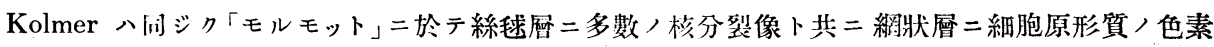
形成次デ夫レ等, 破壞消失. 此, 結果卜シテ細胞索間二空間, 出現 7 見. 之レヨ以テ妊娠期間二 於ヶル特别，所見ナリトシ。雄性二對シ明カ二第二性徵习認ムぶシトナス。然レドモ「ラッテ」「マ ウス」ニ八斯ル所見习見ブト. Donaldson モ「モルモット」及ビ鳩二於テハ副腎肥大ヨ見ルモ「ラッ テ」ニテハ然ラブ. Hatai 八之レニ反シ「ラッテ」ニ於ケル肥大ヨ認メシト云フ. Riddle 八沜二於 テ排卵週期 二副婜，週期的肥大ヨ認メシト云フ。ーウス」ニ於テハ增井。田村ハ受胎スレバ絴狀

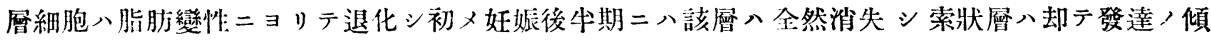

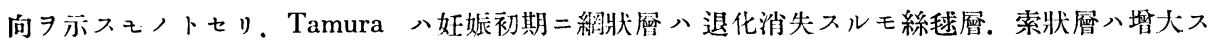
ルヨ以テ副腎、全體トシテ肥大ス而シテ娃帐第 15 日頃二極大トナルト. Miller 八前訅增井等，

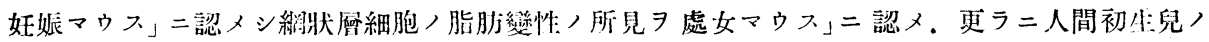

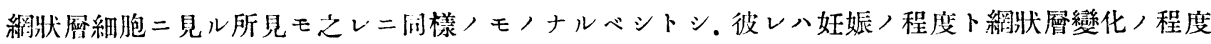

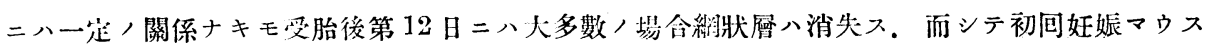

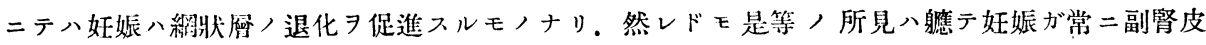

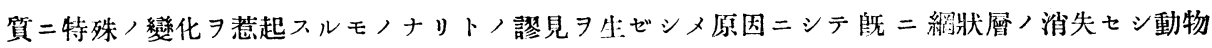

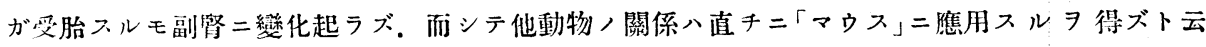
ヘリ。

\section{第二項 檢查動物二關スル泩意}

觀察セル動物數ハ 25 ニシテ余，侗養繁殖セルモノヨ交尾好娠セシメタルモノナルモ各個動物 


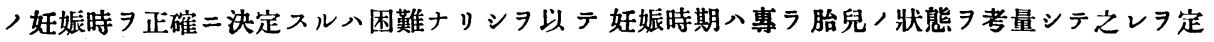
メタルハ遺㫼ナリトス. 而シテ娃娠時期八大體初期中期末期二分チ. 是等ノ所見 7 求メタルモ， ナリトス。

\section{第三項 妊娠時ニ於ケル「マウス副腎皮質/組織的所}

$$
\text { 見二關スル總括的觀察 }
$$

奸帐時ノ「マゥス副腎皮質ノ組織的所見八。大體正常成長雌マウス」ニ於ヶル皮質網狀層細胞 體內脂肪沈著 7 來タセルモノ二類スル場合多キ 7 以テ(第 268 號. 第 530 號). 各例二於ヶル個々 ，所見习詳細二訅述スルコトナク．直チ二總括的二是等觀察スルコト、ス。・

雌性マウス發育中及ビ發育後ノ副腎皮質網狀層ノ生理的變化, 程度八個體ニョリ著 シキ相違フ認ムべキハ上述セルガ如シ. Long-Evans ハ「ラッテ」ニ於ケル觀察ニ依ル 二生後第一回ノ排卵 來入時期二就テモ個體ニョリ103日ノ動搖アリト云へルガ如キ 元 $コ$ 生殖腺機能其, 他二複雜, 事情アルベキモ是等, 關釈八更ラ二生殖腺卜密接,

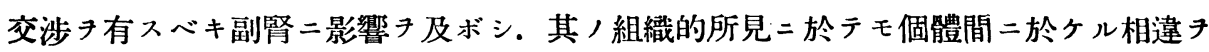
生ゼシムル原因トナルチ得べキカ. 斯クノ如ク常態二於テ副腎皮質網狀層八各個體二 ヨル相違キ示スベキモ。一度受胎スルニ至レバ多クノ場合立幺一定ノ變化ヲ示ス二至 ル. 即于既二正常䧳マウス第 268 號及ビ第 530 號二述べタルガ如ク網狀層細胞體內二 脂肪沈著き來シテ漸次退行的變化二陷リ。從テ該層，退縮き來ス場合アルモノトス。

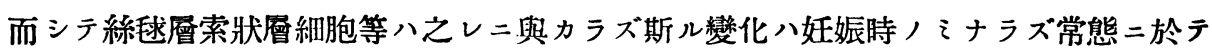
モ時ニ認メラル、所見ナルガ. 該變化ヨ起シツ、アル動物ガ受胎セル場合二於テハ常 態二於ケルョリモ急速二進行ス. 表 VI 二於テ妊娠動物卜同腹處女動物卜，網狀層細 胞變化ノ程度及ビ該層原徑フ比較スベシ。

(表 VII)

\begin{tabular}{|c|c|c|c|c|c|c|c|c|c|}
\hline & 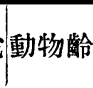 & 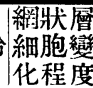 & & 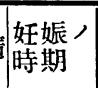 & 動物番號 & & 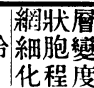 & 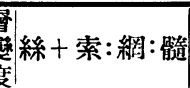 & 月 \\
\hline & & $\begin{array}{l}+H \\
+\end{array}$ & $\begin{array}{l}10: 2.3: 8.3 \\
10: 14.1: 12.4\end{array}$ & 最初期 & & & H & $\mid \begin{array}{l}10: 3.3: 9.1 \\
10: 11.0: 13.6\end{array}$ & 末期 \\
\hline & & \pm & & 最初期 & & & $x$ & $\left|\begin{array}{rlrr}10: & 0 & : 9.1 \\
10: & 9.0: 12.1\end{array}\right|$ & 5 \\
\hline & & $\begin{array}{l}x \\
+\end{array}$ & $\left(\begin{array}{lll}10: & 0 & : 1 \\
10: & 8.2: 1\end{array}\right.$ & 期 & & & $\underline{x}$ & 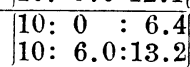 & (1) \\
\hline & $\begin{array}{l}99 \text { 日 } \\
99 \text { 日 }\end{array}$ & $x$ & $\mid \begin{array}{rlr}10: & 0 & : 14.5 \\
10: & 9.2: 22.1\end{array}$ & 期 & & $\begin{array}{l}108 \text { 日 } \\
108 \text { 日 }\end{array}$ & HI & $\begin{array}{l}10: 1.9: 8.1 \\
10: 7.3: 8.5\end{array}$ & 初声 \\
\hline
\end{tabular}

卅…網狀層細胞, 退行的戀化高度, モ,

$+\cdots \cdots$ 一輕度, モ,

$-\cdots$ 網狀層細胞二退行的變化 7 認メザルモ,

$\times \cdots \cdot$ 網狀層細胞退化消失シテ僅カ二其, 痕跡ヨ止ムルモノ 
上表ニ見ルガ如ク對照動物ニ於テハ 8 例中 5 例二於テ少網狀層細胞ノ變化き認メ ズ. 3 例二於テ輕度/變化 見ル二對シ弤娠マウス」二於テハ 8 例中 4 例八既二該層

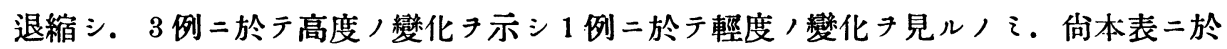
ケル動物ハ皆初司妊娠ノ゙チ選ブ. 經產ノモノニ於テハ所見複雜トナルチ以テナリ。

妊娠動物 /齡及ビ妊娠，時期的關係八個々，動物二於テ必ズシモ細胞變化程度ト八 一致セザルガ如シ. 郎チ一方妊娠初期二於テ既二高度, 變化キ示スモノアルニ拘ラズ. 妊娠末期二於テ少變化ノ程度甚シカラザル場合アリ。是等八受胎時ニ於ケル各個體副 腎, 狀態二原因スルモノナルベキモ．妊娠，經過卜共二細胞變化ノえレニ伴フテ隻涉 スベキハ㓜論ナリトス. 動物ノ受胎後網狀細胞體內二脂肪沈著き來ス二至レバ各個ノ 細胞八腫大シ從テ網狀層全體トシテ八其ノ容積キ增大シ該層, 厚徑加ハル. 而シテ絲

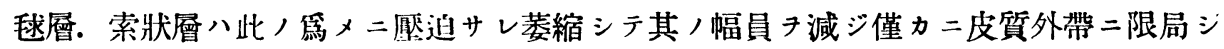
テ存在スルニ過ギザルコトアリ．然レドモ此ノ狀態ノ永續セズシテ短時日二經過シ去 ル場合二於テハ一度肥大七シ副腎八再ビ縮小スルニ至ルベシ. 即千妊娠時二「マウス

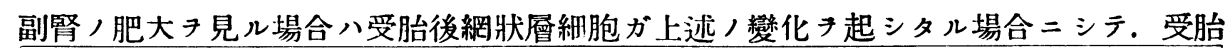

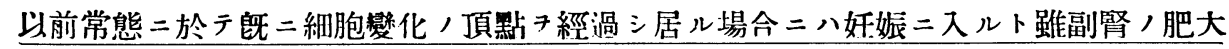

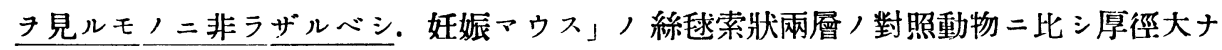
ルハ網狀層退縮ノ結果反應的二增大七ルモノト見ルベシ。網狀層細胞八雌性成長マウ ス」ニテハ常態二於テ脂肪沈著二因ル退行的變化キ來ス場合二於テモ一度受胎スレバ 是等, 戀化急速二進行スル, 事實キ如何二考虑スベキカ. 而シテ常態二於テ是等變化 ノ筂スル時期ガ恰カモ生殖腺成熟後二相當スルノ事實ヨリシテ先ヅ生殖腺機能卜本變 化卜ノ間二八或ル關係, 存在ナ思考シ得べク. 而シテ生殖腺機能ノ狀態モ前述七ルガ 如ク必ズシモ年齡,そチ以テ律シ得べキモノニ非ラズシテ個體二於ケル著シキ相違き 認ムルノ事實八軅テ網㹜層細胞二現ハル、戀性現象ノタトへ同腹動物タリトモ各個體 ノ示ス相違二或ル關係キ有スルモノナルベシ。而シテ受胎後細胞變化ノ急速二進行ス ルハ㦼二正常成長動物二存在七ル或ル種，原因が奸娠卜共二急速二增加セル結果卜シ テ見ルチ得ベキカ. 例へバ單二沺巢機能, 穴進セル二因ルカ. 果タ又胎盤. 胎兒等ヨ リノ刺戟之レ二加ハリタルニヨルカ. 是等, 事俄カ二決入可ラズト雖卵巢機能, 之レ 二關與セルコトハ想像二難カラザルコト、ス. 殊二去勢後二於テハ以上ノ變化き生ゼ ザルノミナラズ却テ網狀層細胞，新生增殖スル，事實二見テモ然り。少成熟雌性動物

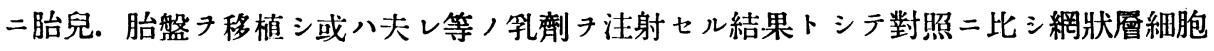

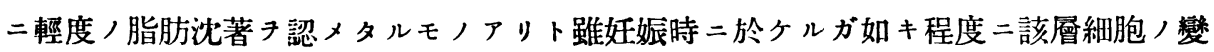


化き惹起シ得ザリシ八或ハ刺戟物質ノ量的差異二因ル結果ニ非ラザルカ. 㑤腦下垂體 前葉ホルモン」ノ卵巢二對スル關係八後述スベキモ妊娠時ニ於テハ常態二比シテ約 1000 倍ノ該ホルモン」尹血清中二證明スルチ得タリシト云フZondek 成績キ考量ス ルモ是等ノ關係八更ラニ副腎二對シテモ相當ノ影響キ與へ得べキハ想像ニ難カラザル コトナリトス。

\section{第三章 出産後ニ於ヶル「マウス副腎ノ變化}

\section{第一項 文 獻}

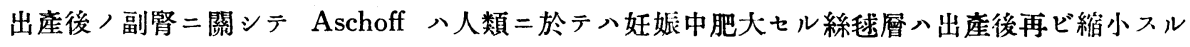

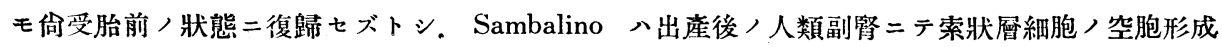

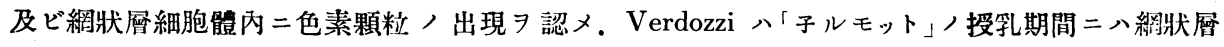

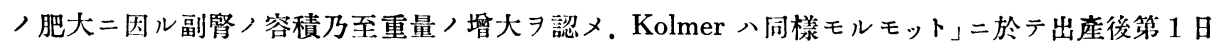
ヨリ10日迄八網狀層八幅員二大差ナク. 絲十索: 網=8.0:3.0八比 7 示スモ. 第 30 日二八 9.2 :6.0トナリ.第 45 日ニハ 5.0:5.0トナル. 而シテ生殖期間习經過セルモノニ於テハ再ビ 8.0:3.0

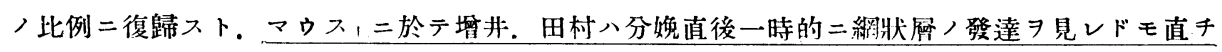

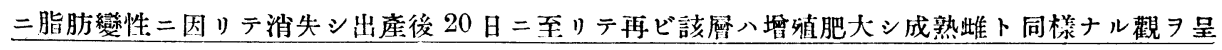
スト. Miller 八同ジク「マス 10 例二於テ分娭後第 1 日卜 5 日一-14日ノモノ二於ヶル所見二大 差ナシトセリ。

\section{第二項 檢査材料動物二關スル注意}

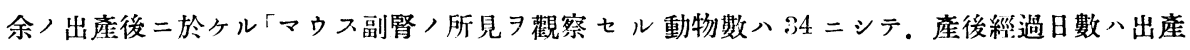

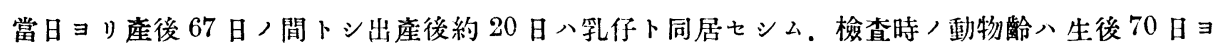

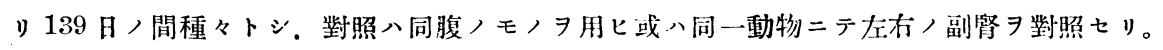

\section{第三項 出產後ニ於ケル「マウス副腎皮質ノ組織的所見}

大體二於テ出產後二於ヶル副腎，所見八妊張期，延長卜見ルフ得ベシ．第 381 號左側副腎、

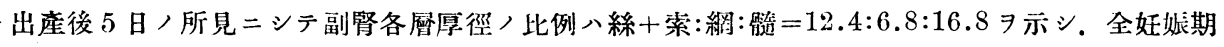
間习經過セルモ侗相當, 綱狀層习殘存セル例ニシテ本層細胞中脂肪沈落 7 來タセル八約其ノ牛

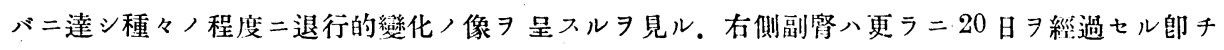
出座後 25 日, 所見ニシテ. 大倒副腎二比スルニ網狀層, 退化更ラ二進ミテ上下雨極二僅カ二退

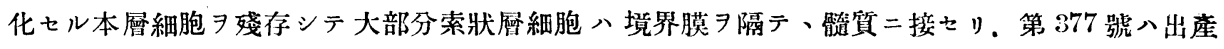

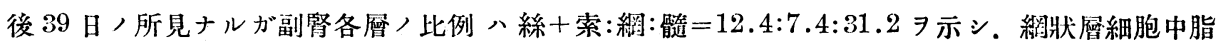

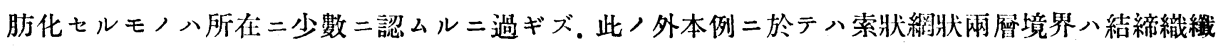

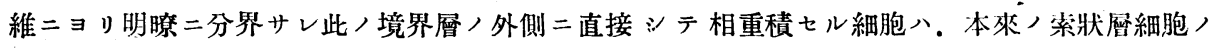
胞體內蜂窠狀 7 呈シ細胞各個ノ境界制然タルト核ノ配置踈ニシテ整然タルニ比シ. 各個細胞ノ境 界明暸ナラズ. 核小ニシテ密接存在シ。胞體內蜂窠狀ヨ示サズ。エオジン可染質ニ富ミタル等上 


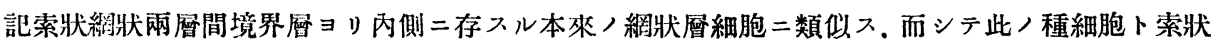
層細胞卜相隣接七ル部分二於テハ雨者雜然トシテ混在シ。恰力モ成長後/雄マウス」ニ去勢 セル場合二新生セル網狀尿細胞二類似セル像习示セり。

\section{第四項 前項二關スル總括的䙼察}

マウス」ニ於テ弤娠ヨ經過シ授乳期及ビ其ノ後ノ經過二於ケル副腎ノ所見中皮質絲

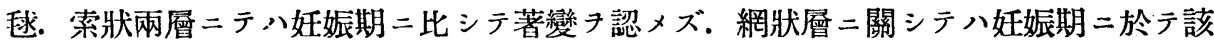
層細胞體內二脂肪沈著尹來タシ. 次デ退行的變化二陷リ網狀層，退縮き促進サル、モ ノアルモ全弤娠期間 ヨ經過スルモ倘該細胞層ノ殘存セル場合アリ。例之 38 例中 18 例 八完全二退縮シ 11 例八其ノ痕跡キ殘シ 9 例二於テハ程度 二强弱アリト雖明暸二該層 ノ殘存セルナ見ル.而シテ立二殘存セル網狀層細胞,出產後ノ經過二於ケル變化如何. 前述第 381 號二於ケル左右副餐, 所見尹比較スル二出產後モ少妊娠期間内二行ハレ ル該細胞ノ退化機轉八中絶七ザルキ見ルベク．少第 377 號二於ケルガ如ク產後 39 日 キ經過スルモ机當厚徑ノ網狀層タ有シ且ツ細胞變性ノ程度モ甚シカラザル所見ヨリシ テ出產後二於テ八或八退化機轉き中止スルカ或ハ少ナクトモ其ノ經過緩慢トナルモ， アルベキキ想像シ得べキモ是等,點二關 シテハ正常此成長マウス」/網狀層二於ケル 關係ト同ジゥ個體ニヨル相違ノ甚シキモノアルベキナ以テ全體二於テ略?一致七ル所 見き舉グルハ困難ナリトス。而シテ交獻二於ケルガ如キ分娩直後一時的二網狀層發達 シテ直チ二脂肪變性二陷り。更ラニ 20 日ナ經テ該曆增殖發達 シテ正常ノ程度二達ス ルト云ヘルガ如キ所兒ハみレキ認ムルキ得ズ. 少產後 1 日ノ所見ト 5 日一14日二於ケ

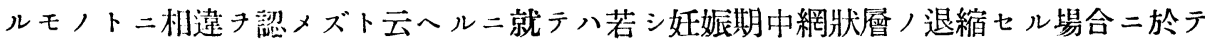
八大體ニ之レチ認メ得ベシトスル倘該層, 殘存セル場合二於テハ事情異ナルモノトス

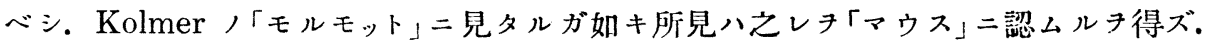

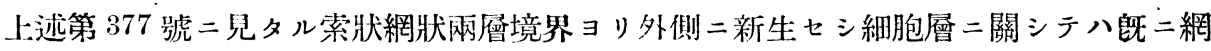
狀層，退縮セル動物フ去勢七ル埸合二新生七シ網狀層，所見二對照シテ或ハ新生網狀 層細胞トシテ見ルキ得ンカ。本新生細胞層，出現程度八例之 38 例中 12 例 認ムべク 全然存估セザルモノ 15 例. 不明暸ナル程度ノモノ 11 例ナリ．而シテ本細胞層/出現 八大體二於テ產後ノ經過日數二正比例スルガ如キモ相當時日キ經過スルモ之レキ認メ ザルモノフルダ以テ是等ノ點二關シテモ各個性,相違二歸スベシ。皮髓兩質間二出現 スベキ内被膜二關シテハ網狀層，退縮セルモノ二八勿論出現スべク. 即チ 38 例中 31 例ノ出現ヲ見. 7 例二於テハ之レテ認メズ，郎チ網狀層／殘存七ル數二略了匹敵ス。 
(表

VIII)

\begin{tabular}{|c|c|c|c|c|c|c|c|c|c|}
\hline 動物番號 & 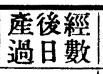 & 網狀層 & 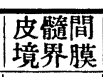 & \begin{tabular}{l|} 
新生細| \\
胞層
\end{tabular} & 動物番號 & \begin{tabular}{|l} 
產後經 \\
過日數
\end{tabular} & 網狀層 & 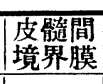 & \begin{tabular}{|l|} 
新生細 \\
\end{tabular} \\
\hline 519 & 1 & - & + & - & 612 & 25 & - & + & - \\
\hline 380 左 & 1 & + & - & - & 614 & 25 & - & + & $H$ \\
\hline 582 & 2 & $\mathrm{~S}$ & + & $\mathrm{S}$ & 381右 & 25 & $\mathrm{~S}$ & + & - \\
\hline 381左 & 5 & $H$ & - & - & 558 & 29 & - & + & + \\
\hline 588 & 5 & - & + & - & 611 & 30 & $+(F)$ & + & $\mathrm{S}$ \\
\hline 583 & 6 & $\mathrm{~S}(\mathrm{~F})$ & + & - & 378 & 34 & 世 & - & $\mathrm{S}$ \\
\hline 590 & 11 & - & + & - & 609 & 35 & - & + & + \\
\hline 589 & 14 & - & + & + & 377 & 39 & tt & - & + \\
\hline 373 & 14 & $H(F)$ & - & - & 376 & 41 & $\mathrm{~S}$ & + & + \\
\hline 544 & 15 & - & + & $\mathrm{S}$ & 375 & 42 & $\mathrm{~S}$ & + & - \\
\hline 545 & 15 & - & + & - & 345右 & 44 & $\mathrm{~S}$ & + & + \\
\hline 600 & 17 & - & + & - & 346 右 & 44 & $+(F)$ & - & + \\
\hline 577 & 20 & $\mathrm{~S}$ & + & + & 566 & 46 & $\mathrm{~S}$ & + & + \\
\hline 543 & 22 & - & + & $\mathrm{S}$ & 374 & 47 & - & + & - \\
\hline 380右 & 22 & $\mathrm{~S}$ & + & $\mathrm{S}$ & 501 & 48 & - & + & $\mathrm{S}$ \\
\hline 345 左 & 22 & $\mathrm{~S}$ & + & $s$ & 476 & 49 & S & + & $\mathrm{S}$ \\
\hline 346 左 & 22 & $+(F)$ & - & $\mathrm{S}$ & 518 & 51 & - & + & - \\
\hline 532 & 24 & - & + & - & 474 & 60 & - & + & $\mathrm{S}$ \\
\hline 517 & 25 & - & + & + & 483 & 64 & + & + & Ht \\
\hline
\end{tabular}

$\mathrm{S} \cdots$ 痕跡的二存在セル

(F)細胞骿八脂肪化セルヨ示ス

\section{第四章 生殖腺未熟マウス體內二腦下垂體前葉成分輸}

\section{入ノ副堅皮愳二及ボ ス影響}

\section{第一項 文 獻}

Zondek u. Aschheim =從へバ腦下垂體前葉八其ノ狀態上生殖腺卜特殊ノ關係ヨ有シ。一般的 二生殖腺ノ機能习誘發スベキ特殊ノ「ホルモン」ヨ藏スルモノナリト七リ。而ンテ其ノ機能上前

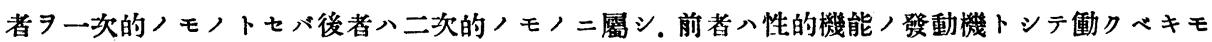
ノト見ルヨ得ベシ.今幼岈ナル雌マウス」二腦下垂體前葉ノ一片习移植スレバ100時間後二本動 物 7 發情狀態ニ至ラシムルタ得. 即チ前葉ホルモン」ハ卵巢二作用シテ異常早期 $=$ 卵巢ホルモン 
ノ分泌习誘發シ此ノモノ八更ラ二子宮. 胵等二發情期二認メラルべキ各特殊ノ變化 7 發生セシ ムルヨ得ベシ. 然ル二豫メ動物ヨ去勢シテ前葉ヨ移植スルモ斯クノ如キ變化习認ムルヨ得ズト。 而シテ以上/結果八今ヤ一般二承認サレシモノ、如シ。雄マウス仔二於テハ前同樣前葉成分一间

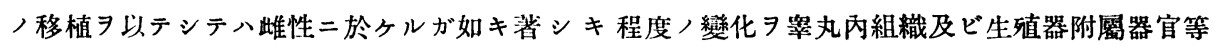
ニ認ムルヨ得ザリシモ數度ノ移植ヨ行フニ於テ八崒丸乃至附屬器官ノ增大习認ムベク (Zondek, Smith) 又前葉，水溶性ホルモン」ノ2-4 マウフ單位ヨ注射スルモ前，場合卜同樣二嶴丸其，他 ノ增大ヨ認ムベシ(Zondek)。而シテ是等ノ關係モ去勢仔ニ於テハ之レ認ムルク得ブト.Biedl 八雌性二於ティZondek，所見二一致スルモ雄性二於テへ却テ抑制的影響习認ムルトシ Steinach 八雄性二於テモ生殖腺ニ及ボス影響大ナリトセリ。

余ハ雄性マウス仔二新鮮ナル馬 腦下垂體前葉ノー片チ移植シ或ハ其ノ乳劑キ注射 シテ是等動物生殖腺機能キ異常早期二誘發シ以テ其ノ副腎皮質二及ボス影響キ觀察セ リ。

\section{第二項 檢査材料動物選定二關スル泩意}

動物ハ雄仔二於テ試驗二供セルハ 12 例ニシテ生後 20 日以前ノモノ 八種々トス。而シテ是等試驗動物, 檢查ハ少ナクトモ生後 30 日以前ニ行フモノトス。郎手常態 二於テ皮筫網狀層細胞，咼充分二保存サル、期間內. 少ナクトモ該層細胞二退行的變化 ル以前ニ之レヨ觀察スル必要アレバナリ. 對照動物ハ同腹ノモノニテ嚴重二發育其ノ他 7 顧慮シ テ之レヨ選定セり．雌性マウス仔ニ於テハ前葉ホルモン」ノ生邪腺ニ及ボス影響顯著ナルニ拘八 ラズ.副腎皮質網狀層, 構造八前迅, 如ク生殖腺成熟後二於テハ常態ニテ.各個體/示ス相違甚シ キモノアリ. 從テ雌性二於テハ雄性二見ルが如キ生殖腺成熟期二相當シテ網狀層細胞二起ル略了 定型的ノ變化 7 目標トシテ前葉ホルモン乃至生殖腺ホルモン」ノ影響 性, 網狀層細胞二特殊, 退行的變化 $\ni$ 起又場合八多ク 八生後 50 日一-60日以後ナル 7 以テ賽驗時 期モ雄性同樽必ズシモ生後 20 日以前卜限定セズ。

\section{第三項 雄性マウス仔體內二腦下垂體前葉成分輸入後 ノ副腎皮質組織的所見及ビ観察}

第 521 號。雄マウス(生後 20 日)腹腔內二新鮮ナル馬ノ腦下垂體前葉ノ一片 $ヨ$ 移植シ。 5 日後

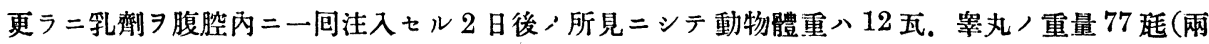
側)．對照ニテハ體重 13 瓦．崒丸八重量 68 瓦．副堅ノ組糡的構造ニテ對照卜著明ナル相違ヨ示 ス八索狀網狀兩層細胞及ビ皮䯕境界部八所見ナリ。絲速層八對照ト大差ナシ. 索狀層細胞八對照

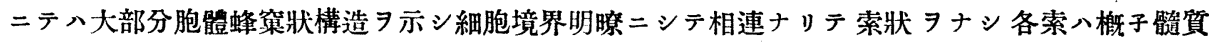

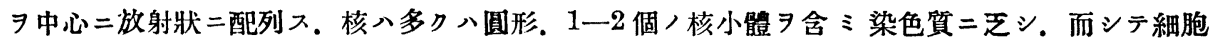

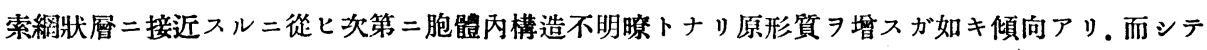

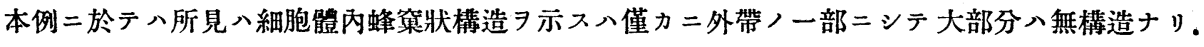
而シテ胞體內原形質二富ミ。對照二於テ網狀層二接近シテ存スル細胞二類似ス. 各細胞境界モ對 照ニ比シ概子不明暸ナリ．索狀，網狀兩層，境界八對照ニテ入明暸 
ヨリナル境界層ニョリテ識別可能ナルノミナラブ，本細胞及ビ網狀層細胞 ニハ核ニ接近シテー

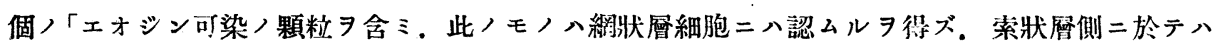

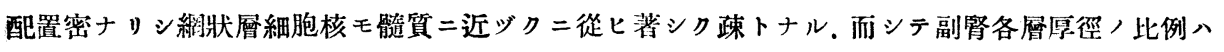

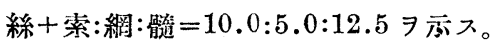

斯クノ如未對照動物ノ所見二比シテ本例二於テハ著シキ相違き認ムルハ網狀曆細胞 ノ關係ナリ。本例二於テ，髓質八大部分直チ二索狀曆二接シ。網狀曆細胞卜シテ認ム ベキモノ八僅カ二部分的二存在スル二過ギザルガ如ク. 從テ皮髓境界モ略?直線的二

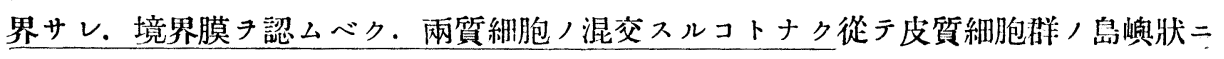
髓質內二混在スルモノモ之レキ認メズ. 即チ本例二於テ八網狀層，退縮明暸ナル皮髓 境界膜，形成等正常成育雄マウス副留，定型キ示七ルキ見ル. 而シテ皮髓厚徑，比例 八絲十索:髓=11.8:14.3 チ示ス. 對照ニ於テハ網狀層. 髓質間二境界膜ナク兩質緗胞 混交三。殊二髓質內二多數, 皮質細胞群島舆狀二散任ス。而シテ是等, 細色八核ノ形 狀不正トナク漸ク退化ノ傾向キ示シ來ルモ,多キガ如シ. 生殖腺未熟,「マウ入仔體 内二腦下垂體前葉成分/輸入ニヨリ著シク早期二生殖腺成熟乃至其八機能于誘發シ。 從テ第二性徵ノ出現き促ガスモノトスレバ本例ノ所見八生殖腺早熟ノ結果早期二機能

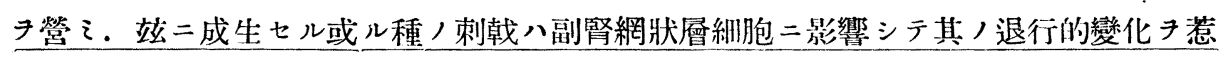
起七ルモノト思考サルベク，郎チ雄性マウス該緗胞機能卜生㱠腺機能卜，間二密接ナ ル關係キ想像スルコトキ得ベシ。

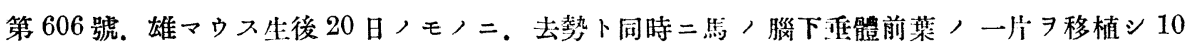
日後, 副腎, 所見。

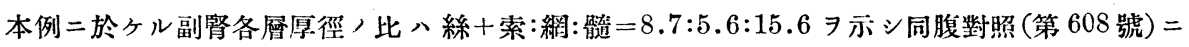

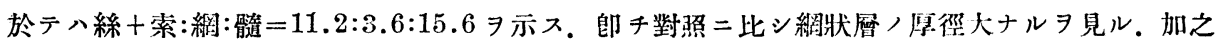

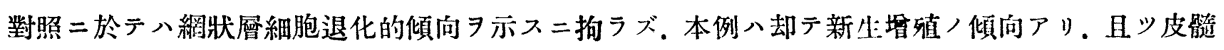
兩質境界モ不明 ニシテ膸質内二皮質細胞群, 混入甚ダシク. 恰力モ單二去勢习行へルモ, 、所

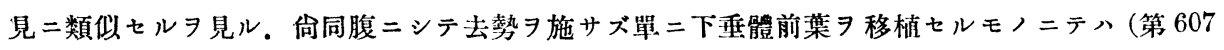

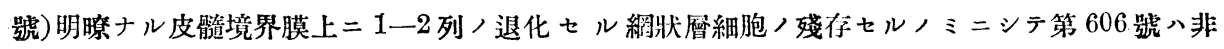

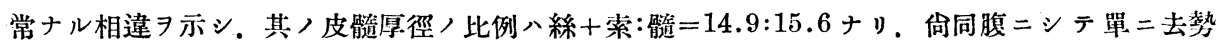

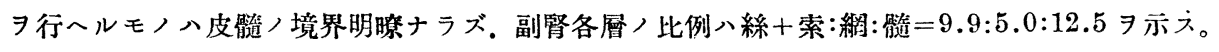

要之腦下茾體前葉移植ノ結果. 副腎網狀層細胞, 早期二退化消隇スル䉆メ二八生殖 腺ノ存在き必要トスルハ.上述第605號ノ所胃ニョルモ明ラカナルガ如ク. 腦下垂體 前葉ノ影響八直接二副䁂二働クモノニ非ラズシテ先ジ生殖腺ニ作用シテ其ノ機能ア覺

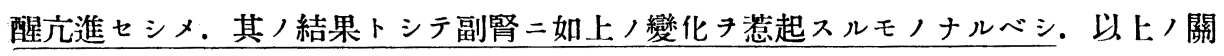
係八幼弱雌性マウス」二於テ腦下垂體前葉移植卜同時二去勢き施七バ上述セル特異ナ ル第二性徵ノ早期出現ヨ見ザルZ Zondek 等ノ所見ニ一致スルモノナルベシ。 


\section{第四項 前項試驗後二於ケル峷九，所見及觀察}

上述七ルガ如ク「マウス仔體內二腦下垂體前葉移植或ハ水溶性ホルモン注入，睪丸 二及ボス影響如何二關シテ Zondek 八是等試驗, 結果增大七ル睪丸二於テ增殖セル 八間細胞ナリヤ精系細胞ナリヤキ決定シ能ハザリシト七ルガ. 余，例二於テ八睪丸八 外觀且ツ重量二於テ對照卜著シキ相違ナキモ組織的二八試驗的物ノ造精細胞二特二對 照二比シテ發育ノ程度增進七ルモノナク。數例二於テハ却テ該細胞, 萎縮狀態認メ シモノアリ．然レドモ細精管間質組織二於テ八間緗咆，增殖血管腔，摴張及ビ「エオ ジン可染，等質性物質，出現尹認メ得べク．從テ全體トシテ間質ノ容積增大セルき認 ムルキ得. 而シテ以上，所見キ以テ睪丸機能卜網狀層細胞卜八間二於ヶル關係タ推測

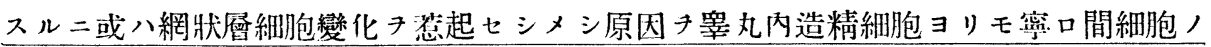

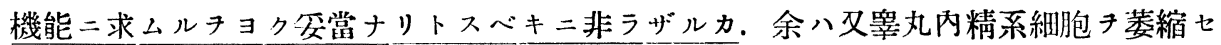

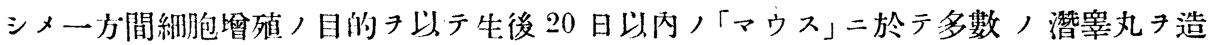
リタル大多數二於テ閒細胞, 多少ノ增殖八諤メ得タルモ精系細胞ノ退化ノ程度弱ク所

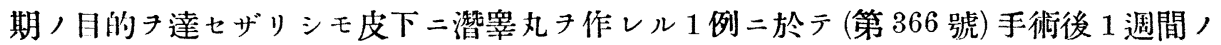
經過中. 間細胞, 非常ナル增殖卜精系細胞, 殆ド完全ナル退化チ來タセル例チ得タリ.

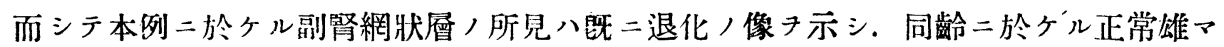

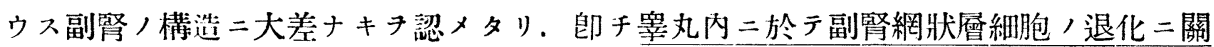
舆スル部分ハ精系細胞二非ラズシテ間紐胞ナラズヤトノ前述ノ推测二幾分ノ根據キ與 ヘル所見ニ非ラザルカ。

\section{第五項 雌性マウス仔體內二腦下垂體前葉成分輸入後}

\section{/副腎皮睤ノ組織的所見及ビ觀察}

本試驗二使用セル動物數ハ11ナリ．而シテ雌性マウス體內二腦下垂體前葉成分輸 入ニヨリ副腎皮質二及ボス影響八前述七ル雄マウス」ノ場合二於ヶルガ如ク明暸ナラ ズ. 常態二於テ雉八生殖腺成熟期二副腎八略?定型チ示シテ動物個々ニヨル相異少ナ キ二反シ. 雌二於テハ此ノ時期二至ルモ個體ニヨル所見八相違甚シキハ㗹テ本試驗二 ヨル結果, 區々タルチ示ス原因トナルモノナルベシ。而シテ試驗動物ニ於ケル網狀層 細胞ノ形態的變化著シカラザルモ. 皮質各磻厚徑ノ比較き見ル二對照二比シテ明カニ 網狀曆，厚徑減少セルチ胃ルチ得ベク. 即チ試驗動物二於テハ絲十索:網=10.0:5.1ナ ルニ對シ對照ニテハ絲十索:網=10.0:8.8 キ示セリ．要之雌性ニテハ雄性ニ於ケルガ 如キ明暸且ツ一定セル所見キ示サズト雖モ生殖腺, 機能覺醒乃至穴進ニョリテ網狀層 
細胞ノ退化的傾向ノ促進サル、チ想像シ得ベシ、組織的二八網狀層細胞ハ個々ノ境界 不明ニシテ原形質二乏シク錯綜セル結締織織維間二僅カ二殘存セル原形質内二核散在 シ或八萎縮シ破壞セルアリ。或八染色質融解シテ僅カニ陰影キ止ムルモノ等著シク退 行的戀化キ示シ髓質内二八皮質細胞群侵入混在シテ兩者/境界チ不明ナラシム．表IX 八雌マウス」ニ腦下垂體前葉き移植シ或ハ乳劑キ注射セルモノニシテ皮質網狀層厚徑 ノ對照ニ對スル比較キ示シタルモノナリ。

(表

$\mathrm{XI})$

\begin{tabular}{|c|c|c|c|c|c|c|c|}
\hline $\begin{array}{l}\text { 動物 } \\
\text { 番號 }\end{array}$ & 動物路 & 絲一 & 絲十 & $\begin{array}{l}\text { 動物 } \\
\text { 番號 }\end{array}$ & 動物踰 & 絲十索: 網 : 髓 & 絲十索 : 網 \\
\hline $\begin{array}{l}477 \text { 號 } \\
\text { 對 照 }\end{array}$ & $\begin{array}{l}42 \text { 日 } \\
42 \text { 日 }\end{array}$ & $\begin{array}{r}15.6: 7.4: 17.5 \\
9.3: 6.8: 11.2\end{array}$ & $\begin{array}{l}10: 4.7 \\
10: 7.3\end{array}$ & $\begin{array}{l}467 \text { 號 } \\
\text { 對 }\end{array}$ & & $\begin{array}{r}15.5: 11.2: 21.8 \\
9.3: 10.6: 20.6\end{array}$ & $\begin{array}{l}10: 7.3 \\
10: 11.4\end{array}$ \\
\hline \begin{tabular}{|l}
433 號 \\
\end{tabular} & $\begin{array}{l}44 \text { 日 } \\
44 \text { 日 }\end{array}$ & $14.9: 4.3: 11.7$ & $10: 2.9$ & & 52 日 & $9.3: 15.6$ & $10: 4.7$ \\
\hline 434 號 & 48 日 & $14.3: 10.5: 20.0$ & $10: 7.3$ & 508 號 & 64 日 & $19.3: 6.8: 18.7$ & $10: 3.5$ \\
\hline & 3 日 & 11. & $10: 8.9$ & 對 & 64 日 & $11.1: 11.8: 21.8$ & $10: 10.6$ \\
\hline
\end{tabular}

\section{第三編 以上各章ニ於ヶル總括的觀察中ノ要點}

1. マウス副腎皮質二於テハ出生當日既二明ラカ二分類シ得べキ内外 2 種，細胞層

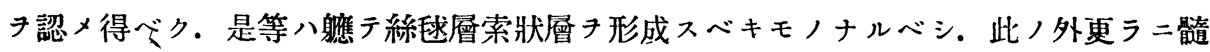
質細胞二接シテ所々二胞體小ニシテ境界明暸ナル一種ノ細胞ノ散在七ルき認ム後チ， 網狀層細胞ノ原基タルモノナルベシ。

2. マウス生後 11 日二於テハ上記網狀層二屬スベキ細胞八漸次增殖シテ既二一層 形成セルモノトシテ見ルナ得ベキモ生後 15 日二至レバ更ラ二明暸二本層き識別シ得 ベキモノトス. 而シテ生後 17 日一18 日二於テ八絲㲑層. 索狀層二屬スル細胞八其 配列ノ狀態及ビ形態的性狀二於テ雌雄, 別ナク概子成長後, 所見二一致セルキ認ムべ シ。

3. 雄性マウス生後 20 日一 30 日二於テ八.網狀層細胞八俞了新生增殖シ.從テ該層， 厚徑キ增大ス．茲二增殖スル細胞ハ外方二於テハ索狀層内二不規則ノ侵入ォナス事ナ キ二反シ. 細胞群ハ索狀チナシ髓質內二侵入シ從テ兩者ノ境界チ不明ナラシメ且ツ前 者八島嶼狀二髓質內二混在ス. 生後 30 日一 40 日二於テ上述, 網狀層細胞八核濃縮シ或 八破碎シ原形質モ亦萎縮濃染シテ次第二消失シ從テ該層ノ退縮き來シ. 加之以上ノ經 過中皮髓兩質間二結締織二富メル境界層キ形成シテ兩者/分界明暸トナル。而シテ網 狀層細胞群八僅カ二痕跡き境界層上二殘ス二過ギズ. 斯ル狀態八成熟雄性, 常態ニシ テ所謂雄性副腎, 定型卜ナス. 雌性二於テ八生後 20 日一30日後二於テモ網狀層八雄性 
同樣ノ退化的變化チナサジルノてナラズ却ツテ增殖シテ髓質內二侵入シ. 從テ皮髓兩 質細胞, 混在キ來スコト甚シ。而シテ雄性二見ルガ如キ略々一定七ル網狀愿，退縮期

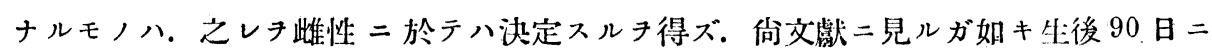
シテ雌性モ雄性同樣/定型的構造キ示スト云へルガ如キ所見ハえレチ認ムルチ得ズ。

4. 雌マウス」ニテモ雄性同樣ナル網狀愿細胞ノ退行的變化き認ムル場合アレドモ此 ノ外二雄性二八認ムルコトナキ。雌性二特有ナル該細狍ノ變化認ムルコトアリ．郎

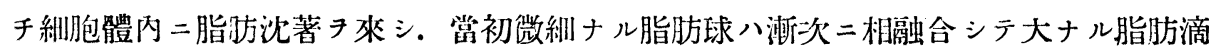
トナリ，或八脂肪キ以テ全胞體キ充タシ恰カモ脂肪細胞, 觀キ呈スルモノアリ。核八 緗胞壁二厴本サレ。或ハ各脂肪滴間二介在㕍迫サレ. 形狀不正トナリ。染色質キ失ナ 七或ハ溶崩破壞シテ遂二消失入。而シテ斯儿變化八發生時期八個體二於ケル異同甚シ キモノトス。

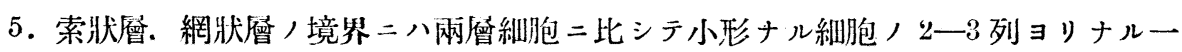

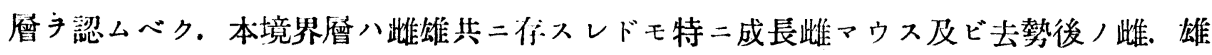
マウス」二明暸二認メラル、コト多シ。

6. 雄マウス」ニテ副腎皮質網狀磻，退縮 スベキ時期二先ダチ(例へバ生後 20 日頃)

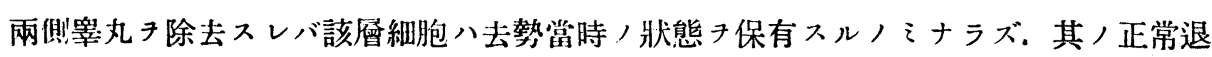
樎期 (生後 30 日一 40 日) 二至ルモ退行的變化キ示サズシテ却テ該層ノ增大キ來タシ.

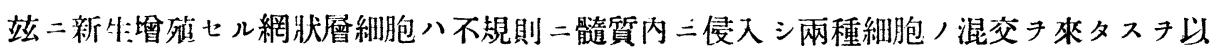
テ. 常態二テ皮髓間二存スル境界膜き形成七ズ，而シテ外方郎チ索狀層側ニテハ新生

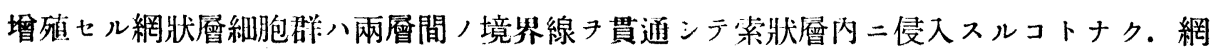
狀層，肥大スル二從七上記境界線ハ全體トシテ其ノ儘外方二移動スベシ。

7. 成長雉マウス (生後 40 日以後ニシテ即チ網狀層)退縮後 $)=$ 去勢チ行へバ皮髓境 界膜.上.痕跡的二殘存七ル網狀層細狍八玆二新生增殖き初ムルモ「 $6 」$ 場合八異ナ リ. 新生細胞八髓質内二侵入スルコトナク，索狀層細胞索間二不規則二增殖侵入ス。 而シテ斯ル場合二八常態二テ索狀網狀兩層間二存スル境界線キ認メザルコト多シ。雌 性二テモ網狀層退縮後二行へル去勢/結果八上述七ル雄性，場合卜略 ?同樣ナリ。

8. 去勢時, 動物跉, 多少卜網狀層增殖程度卜八互二相反スル關係ニアルモ去勢後 ，經過日數卜網狀層增殖程度八或ル期間内二互二正比例ス. 而シテ去勢後增殖セル該 層細胞ハ少ナクトモ去勢後 9 ケ月フ經過スルモ甚シキ變化キ示サズ。

9. 常態二於テ雄マウス」，牛殖腺成熟期二相當シテ副䝳皮質網狀層；退縮スルコ

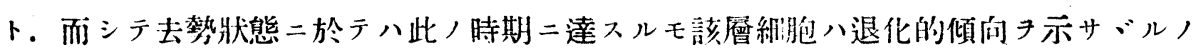


ミナラズ．却テ增殖 繼續スル等ノ事實ヨリシチ生殖腺機能八網狀㕌卜密接ナル交涉 アルコトキ認メザルタ得ズ。

10. 雌マウス」ニテモ雄ト同ジク幼弱時 二去勢スレバ副腎網狀曆細胞ハ或ル時期二 至ルモ其ノ退行的變化キ示スコトナクシテ增殖發達シ。皮髓間二境界膜キ形成セズ. 而シテ成長雌. 特二妊娠時二認メラル、網狀層細胞, 脂肪沈著二ヨル退行的變化八去

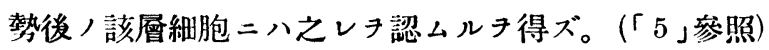

11. 此性二於テ網狀層細胞,脂肪化二因儿退行的變化八弤娠二促進サル、傾问尹示 スモ弤娠マウス」/龄及ビ妊娠ノ時期二八特別，關係子認メザルガ如シ. 而シテ是等 ）變化八雌性二特有ニシテ雄性二認メズ目.去勢後二生ズルコトナク. 然カモ妊娠二 促進サル、等ノ事實ヨリシテ網狀層細胞卜卵巢卜ノ間二特殊, 機能上, 關係子期待 得べキモノナルベシ。

12. 出產後ノ「マウス副筒皮質二於テハ授乳期及ビ其，後，經過二於テモ絲逮層. 索

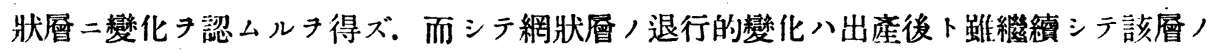
消失スル場合アルト共二該變化ノ淮行セザル場合アリ。而シテ是等ノ關係ハ出產卜共 二其ノ生殖腺機能狀態モ略?常態二復スベキキ以テ各個體二於ケル生殖腺機能狀態， 相違二基クモノト見ルタ得ベシ。アウス」二於テ出産直後一時的網狀層ノ發達尹見. 直チニ脂肪變性二陷り更ラニ20. 日タ經テ正常成長後二於ケルガ如キ程度二再ビ該曆 二發達スル(交獻參照)ト云へルガ如キ所見ハ之レキ認ムルォ得ズ。

13. 生後 20 日以内ノ雄マウス仔體內二馬ノ新鮮ナル腦下垂體前葉ノ一片フ移植シ. 或ハ其ノ乳劑タ注入スレバ該動物ノ副腎網狀層細胞ハ常態ニテハ未ダ退化的傾向み認 メ得ザル生後 30 日以前二於テ既二退行變性二陷リ從テ該層, 退縮キ來シ.恰カモ常態 ニテ生後 40 日以後二認メラル、ガ如キ定型的ノ雄副腎卜同樣ナル所見キ示ス。

14. 腦下垂體前葉ホルモン」ガ「マウス仔ニ於テ其ノ生殖腺機能き異常早期二誘發シ

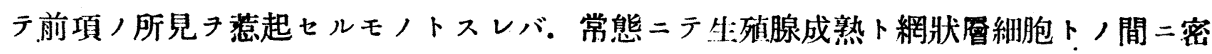
接ノ交涉アルキ証メザルキ得ズ。

15. 雄マウス仔體内二腦下垂體前葉移植卜同時二去勢き施セ, 網狀層, 退縮タ認メ ズシテ恰カモ單二去勢キ行へル動物, 所見二類似ス. 故二前葉成分, 影䍌ニョリ網狀 層細胞二前記ノ變化丹生ビシムルタメニ八生殖腺, 存在キ必要卜ス. 即チ前葉ホルモ ン」ノ副腎二及ボス影響八間接的ノモノト見ルキ得ベシ。

16. $\left\ulcorner 13_{1}\right.$ ，試驗二於ケル睪丸ノ所見トシテハ大體二於テ間緗胞, 增殖. 血管，擴張. エオジン可染，同質性物質，出現等二因ル間質組織，容積增大キ認ムベキモ紐精管內 
二於ケル精絲緗胞二八. 時二其ノ退化像き認ムルコトアルモ發有程度二八對照二比シ

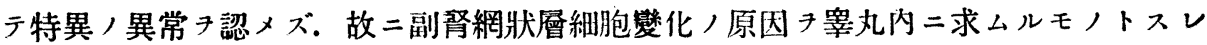

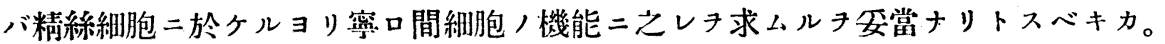

17. 雌マウス仔二テ前記前葉成分，網狀層二對スル影響卜シテ八大體二於テ對照二 比シ該層，退縮セルキ認ムルチ得べキモ雄性二於ケルガ如キ. 明暸且ツ一定セル所見 ヨ示サズ. 恐ラク常態二於テモ網狀層，點二關シテ雌倠間二存スル相違ガ此ノ場合二 於テモ同樣ノ關係キ示スモンナル心゙シ。

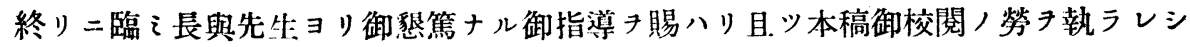
二對シ感謝ノ意 表シ。份多大ノ御助言 キ賜ハリシ三田村博上二感謝ス。

\section{主要文趿}

1) Altenburger, Kastration und Nebenniere. Pflitger. Arch. f. d. ges. Physiologie. $1924 \mathrm{j}$.

2) Aschoff, Über die Ortho-und Morphologie der Nebennierenrinde. Vorträge über Pathologie. 1925 j. 3) Bloch, Einiges zur postfötalen Entwicklung der Nebennieren des Meerschweinchens. Virchows Archiv. 1921 j. 4) Bortz, Nebenniere und Geschlechtscharakter. Arch. f. Gynaekologie Bd. 88. 5) Dostoiewsky, Ein Beitrag zur Mikroskopischen Anatomie der Nebenniere bei Säugetieren. Arch. mikr. Anatomie Bd. 27. 6) Donaldson, The influence of pregnancy and lactation on the weight of the Adr. gland. in albino rat. Anat. Recerch Vol. 27. 7) Hett, Beobachtungen an der Nebenniere der Maus. Zeitschr. f. mikro-Anatom. Forschung $1926 \mathrm{j}$. 8) Inaba, Notes on the development of the suprarenolbodies in the Mouse. The Journal of the college of Sience. Imp. Univ. Japan Vol. 4-1891 j. 9) Kichikawa, Untersuchungen über die Beziehungen der Nebenniere zur der Entwicklung der secundären geschlechtsmerkmale. Biochem. Zeitschrift $1925 \mathrm{j}$. 10) Kolmer, Beziehungen von Nebenniere und geschlechtsfunktion. Pflüger Arch. ges. physiologie 1912 j. 11) Kolmer, Zur vergleichenden Histologie. zytologie und Entwicklungsgeschichte der Säugetieren Nebenniere. Arch. Mikrosk. Anatomie 1918 j. 12) Kohno, Zur vergleichenden Histologie und Embryologie d. nebenniere d. Säuger und Menschen. Zeitsch. f. Anat. und Entwicklung 1925 j. 13) Kolossow, Zur Frage des Ursprungs der Fettsubstanzen in der Rinde der Nebenniere. Virchows Arch. Bd. 264. 14) Kolde, Veränderungen der Nebenniere bei Schwangerschaft und nach Kastration. Arch. f. gynaekologie. $1913 \mathrm{j}$. 15) Long and Evans, The oestrous Cycle in the rat and its associated phenomena. Proc. of the Nat. Acad. of Sience. 1922 j. 16) Lipschutz, Les hormones Hypophysaires chez le Cobaye. Comptes Rendus. 1928 j. 17) Miller, A transitory zone in the adrenol cortex, which shows age and sex relationships. Amer. Journal of Anatomy. $1927 \mathrm{j}$. 18) Sserdjukoff, Zur Frage funktionellen Beziehungen Zwischen der Drïzenparenchym des Ovariums und d. Nebennierenrinde. Virchows Arch. $1922 \mathrm{j}$. 19) Smith and Engel, American journal of Anatomy $1927 \mathrm{j}$. 20) Schmidt, Über $\mathrm{Zu}$ sammenhänge zwischen Nebenniere und geschlechtsentwicklung. Virchows Arch. $1924 \mathrm{j}$. 
21) Schenk, Über die Veränderungen der Nebenniere nach Kastration. Bruns' Beitrage f. Chirurgie 1916 j. 22) Takechi, Morphologische Verhalten der Nebennierenrinde nach Kastration, Künstliche Kryptorchismus und Implantation heterologen Keimdrüsen beim Meerschweinchen. Zeitsch. f. Konstitutionslehre 1926 j. 23) Tamura, Brit. journal experi. Biology $1926 \mathrm{j}$. 24) Zondek, Hypophysenvorderlappen und Ovarium Arch. f. gynaekology 1927 j. 25) Zondek, Hypophysenvorderlappen hormon. Klin. Wochenschrift. 1928 j. 26) Zondek, Weitere Untersuchungen zur Darstellung, Biologie und Klinik des Hypophysenvorderlappen. Klin. Wochenschrift. 1929 j. 27) 增井, 田村, マゥス」ニ於ヶル生

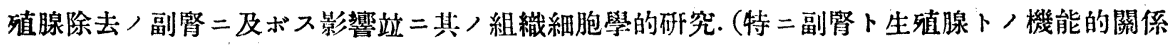
二就テ). 日本婦人科學會雜誌. 大正十三年. 28) 別所，マゥス」副腎/發育二就テ.愛知醫 學會雜誌. 昭和二年. 29) 北川, 副腎摘出, 此性生殖器二及ボス影響二關スル賽驗的研究. 日本婦人科學會雜誌. 昭和二年。 30 ) 松山，パラビオーゼ」ヨ隹用セル賽驗的研究. 日新醫 學. 第入年. 31) 藤田, 采丸內分泌二關スル賽驗的研究. 賽驗醫學雜誌. 大正十三年. 32)

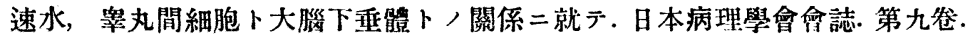

\section{附圖說明（援大ッアイス2-DD）}

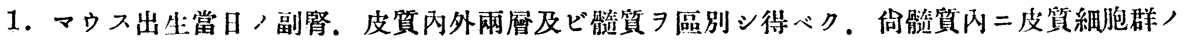
索狀二侵入セル习認ムベシ。

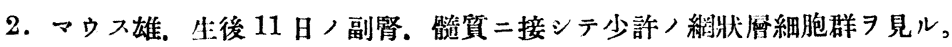

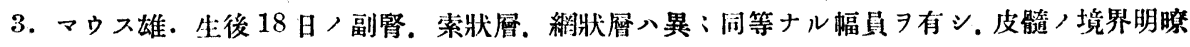
ナラズ。

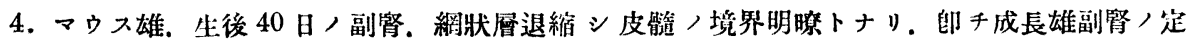
型习示セルモノトス。

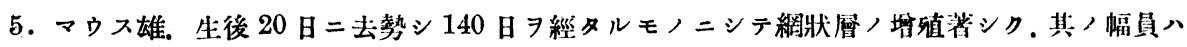
索狀層二此シ約 2 倍强 $コ$ 示ス。

6. マゥス雄。生後 64 日二去勢シ 20 日 ヨ經タルモノニシテ. 皮髓間二明暸ナル境界ヨ形成シ 此, 境界膜上二多少細胞新生ノ徵 $\exists$ 認ムベシ。

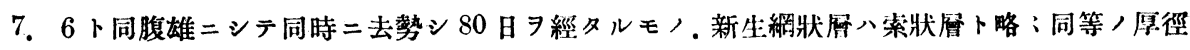
ヨ示ス. 郎千成長後二於ケル去勢ノ影響习認ムルタ得ベシ。

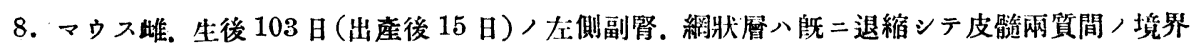
明暸トナル。

9. 8 二於テ左側副腎摘出後 7 日 $\exists$ 經テ去勢シ 31 日後ノ右側副腎, 所見ニシテ新生細胞八皮

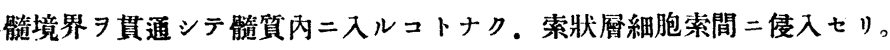

10. マゥ六雌. 生後 107 日。妊娠初期ニシテ既二網狀屏，退縮進行セル

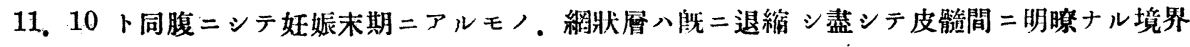
膜习形咸セり。

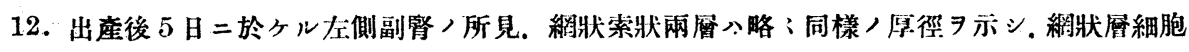
二脂肪化セルモ/ 中等量二存ズ。

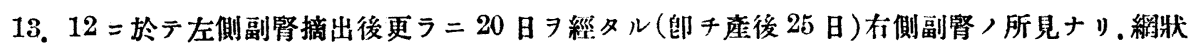
層八殆ド退縮シテ皮體間八原キ境界膜ニテ隔テラル．即千出産後二於テモ該層細胞，退化 
機轉進行スルヨ見ル。

14. マウス雄. 生後 27 日. 生後 20 日二腦下垂體前葉 3 腹䏶内二移植後 副督ノ所見ニシテ. 網狀層八退絔シ皮髓間, 境界明暸トナリ恰カモ雄成長後ノ副腎ノ所見二類ス。

15. 14 卜同腹對照ニシテ絧狀層ノ幅員向廣ク，皮質境界前者ノ如ク明暸ナラズ。

16. マゥス雌. 生後 90 日, 處女八副腎. 網狀層細胞體內脂脂沈著 $ᄏ$ 來. シ各程度, 退行的變化 ヨ示セルモノナリ。(强廓大)

17. マウス生後 27 日, 正常睪丸, 像ナリ。

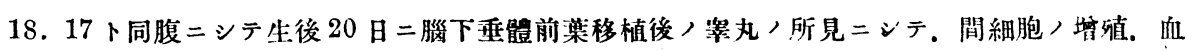
管擴張等ニョル間筫, 增大ヨ認ムルヨ得心゙シ。 
久木田諭文附圖

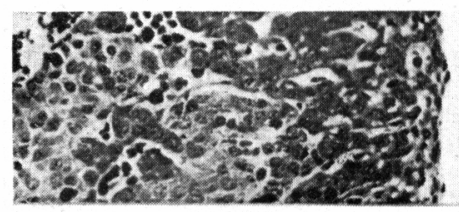

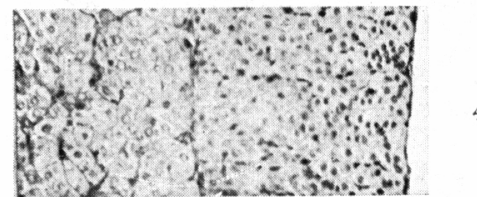
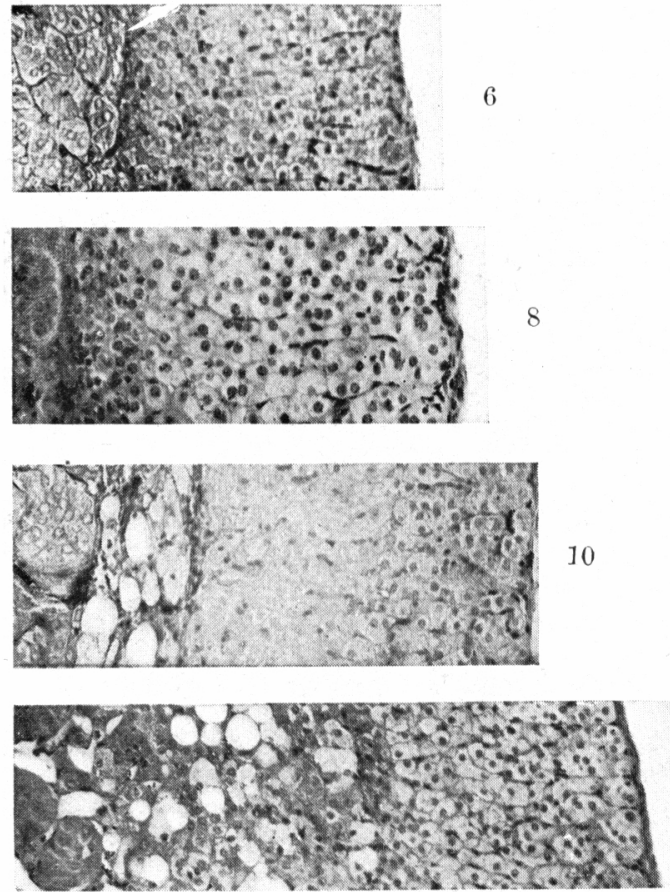

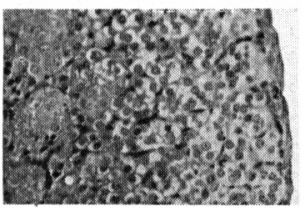

5
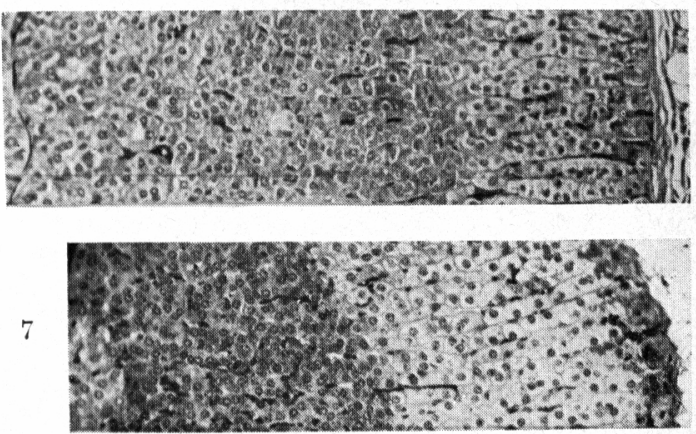

9

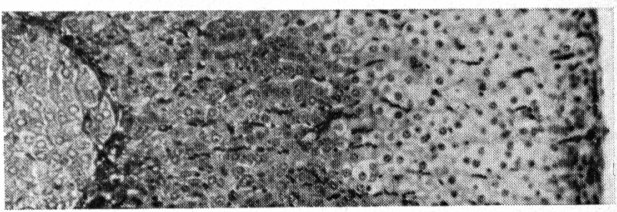

11

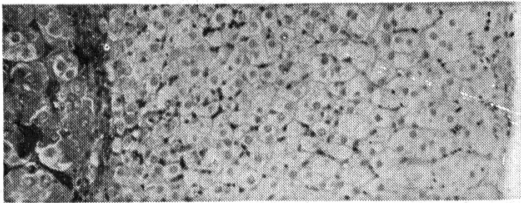

12

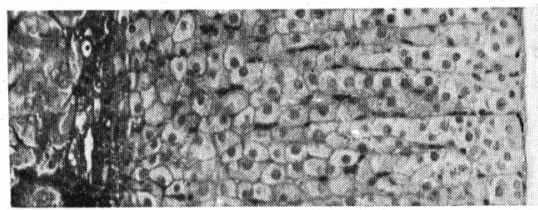

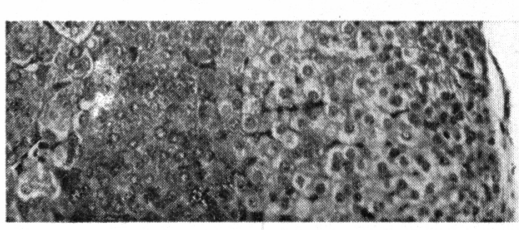

15

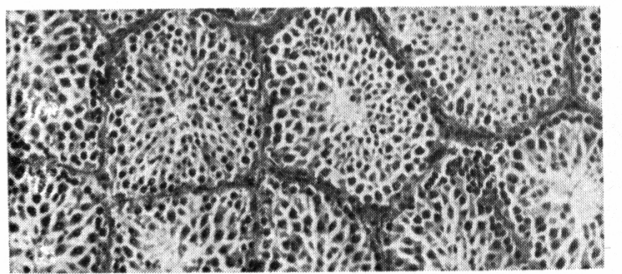

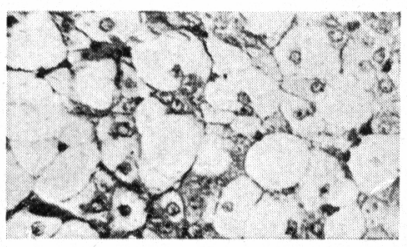

16

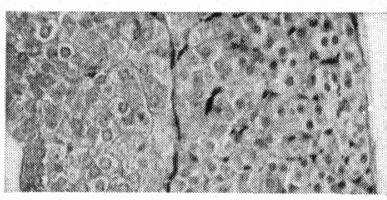

14

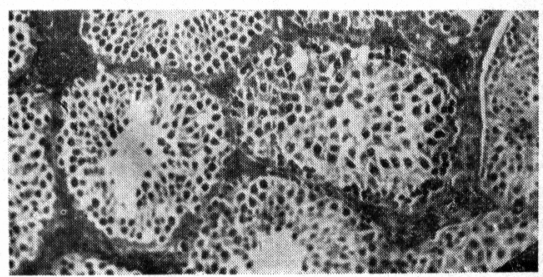

